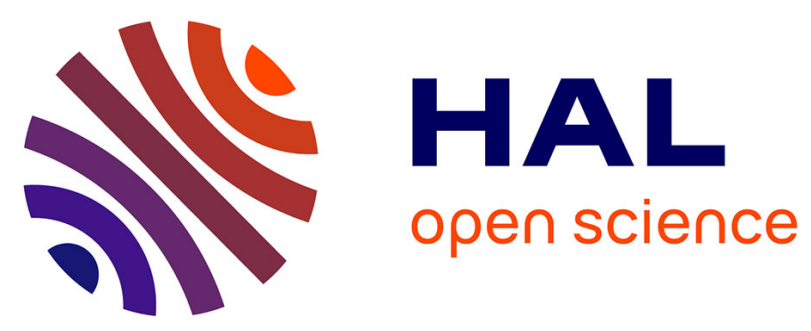

\title{
Alteration-Induced Volcano Instability at La Soufrière de Guadeloupe (Eastern Caribbean)
}

Michael J Heap, Tobias S Baumann, Marina Rosas-carbajal, Jean-christophe

Komorowski, H. Albert Albert Gilg, Marlène Villeneuve, Roberto Moretti, Patrick Baud, Lucille Carbillet, Claire Harnett, et al.

\section{To cite this version:}

Michael J Heap, Tobias S Baumann, Marina Rosas-carbajal, Jean-christophe Komorowski, H. Albert Albert Gilg, et al.. Alteration-Induced Volcano Instability at La Soufrière de Guadeloupe (Eastern Caribbean). Journal of Geophysical Research: Solid Earth, 2021, 126 (8), pp.e2021JB022514. 10.1029/2021JB022514. hal-03419633

\section{HAL Id: hal-03419633 https://hal.science/hal-03419633}

Submitted on 8 Nov 2021

HAL is a multi-disciplinary open access archive for the deposit and dissemination of scientific research documents, whether they are published or not. The documents may come from teaching and research institutions in France or abroad, or from public or private research centers.
L'archive ouverte pluridisciplinaire HAL, est destinée au dépôt et à la diffusion de documents scientifiques de niveau recherche, publiés ou non, émanant des établissements d'enseignement et de recherche français ou étrangers, des laboratoires publics ou privés. 
1 Alteration-induced volcano instability at La Soufrière de Guadeloupe

2 (Eastern Caribbean)

3 Michael J. Heap ${ }^{1,2}$, Tobias S. Baumann ${ }^{3,4}$, Marina Rosas-Carbajal ${ }^{5}$, Jean-Christophe

4 Komorowski ${ }^{5}$, H. Albert Gilg ${ }^{6}$, Marlène Villeneuve ${ }^{7}$, Roberto Moretti ${ }^{5,8}$, Patrick Baud ${ }^{1}$,

$5 \quad$ Lucille Carbillet $^{1}$, Claire Harnett ${ }^{9}$, and Thierry Reuschlé ${ }^{1}$

6

$7 \quad{ }^{1}$ Université de Strasbourg, CNRS, Institut Terre et Environnement de Strasbourg, UMR 7063,

85 rue René Descartes, Strasbourg F-67084, France

$9 \quad{ }^{2}$ Institut Universitaire de France (IUF), 1 rue Descartes, Paris 75231, France

$10 \quad{ }^{3}$ Institute of Geosciences, Johannes Gutenberg University Mainz, Germany

$11{ }^{4}$ Terrestrial Magmatic Systems (TeMaS) Research Platform, Germany

125 Université de Paris, Institut de Physique du Globe de Paris, CNRS, F-75005 Paris, France

$13{ }^{6}$ Department of Civil, Geo and Environmental Engineering, Technical University of Munich,

14 Arcisstrasse 21, 80333 Munich, Germany

$15{ }^{7}$ Department Mineral Resources Engineering, Montanuniversität Leoben, Erzherzog Johann-

16 Straße 3, Leoben A-8700, Austria

$17{ }^{8}$ Observatoire Volcanologique et Sismologique de Guadeloupe, Institut de Physique du Globe

18 de Paris, F-97113 Gourbeyre, France

$19{ }^{9}$ School of Earth Sciences, University College Dublin, Dublin, Ireland

21 *Corresponding author: Michael Heap (heap@ unistra.fr; ORCID: 0000-0002-4748-735X)

23 Abstract

$24 \quad$ Volcanoes are unstable structures that deform laterally and frequently experience mass 25 wasting events. Hydrothermal alteration is often invoked as a mechanism that contributes 
significantly to volcano instability. We present a study that combines laboratory experiments, geophysical data, and large-scale numerical modeling to better understand the influence of alteration on volcano stability, using La Soufrière de Guadeloupe (Eastern Caribbean) as a case study. Laboratory experiments on variably-altered (advanced argillic alteration) blocks show that uniaxial compressive strength, Young's modulus, and cohesion decrease as a function of increasing alteration, but that the internal friction angle does not change systematically. Simplified volcano cross sections were prepared (a homogenous volcano, a volcano containing the alteration zone identified by a recent electrical survey, and a volcano with an artificially enlarged area of alteration) and mechanical properties were assigned to zones corresponding to unaltered and altered rock. Numerical modeling performed on these cross sections, using a hydro-thermo-mechanical modeling code, show (1) the importance of using upscaled values in large-scale models and (2) that alteration significantly increases volcano deformation and collapse volume. Finally, we combined published muon tomography data with our laboratory data to create a 3D strength map, exposing a low-strength zone beneath the southern flank of the volcano coincident with the hydrothermal system. We conclude that hydrothermal alteration decreases volcano stability and thus expedites volcano spreading and increases the likelihood of mass wasting events and associated volcanic hazards. Hydrothermal alteration, and its evolution, should therefore be monitored at active volcanoes worldwide.

\section{Key points}

- Laboratory experiments show that hydrothermal alteration reduces the strength of volcanic rock from La Soufrière.

- Numerical modeling shows that hydrothermal alteration significantly increases volcano deformation and collapse volume. 
- We provide a 3D strength map of La Soufrière that exposes a low-strength zone coincident with the hydrothermal system.

\section{Plain language summary}

The rocks forming a volcanic edifice can be altered by circulating hydrothermal fluids.

This alteration can influence the physical and mechanical properties of these rocks, which could jeopardize volcano stability. The stability of a volcanic edifice is an important consideration in

59 volcanic hazards and risk assessments due to the potentially dire consequences of partial 60 volcanic flank collapse. Using a combination of experimental data, geophysical data, and 61 modeling, and La Soufrière de Guadeloupe (Eastern Caribbean, France) as a case study, we 62 find that hydrothermal alteration decreases volcano stability and thus promotes volcano 63 instability and associated volcanic hazards. As a result, we conclude that hydrothermal 64 alteration, and its evolution, should be monitored at active volcanoes worldwide.

65

66 Keywords: hydrothermal alteration; uniaxial compressive strength; Young's modulus; upscaling; flank collapse 


\section{Introduction}

Volcanoes are inherently unstable structures that are built haphazardly, in both space and time, from the products of successive effusive and explosive eruptions and endogenous growth. These materials have highly variable physical and mechanical properties (Heap and Violay, 2021) and often form oversteepened and unstable slopes. As a result, volcano deformation (such as volcano spreading; Borgia et al., 2000) and mass wasting events (such as debris avalanches resulting from partial flank collapse, lahars, and rockfalls; Roverato et al., 2021) are commonplace at many volcanoes worldwide. Catastrophic collapse resulting from volcano spreading (van Wyk de Vries and Francis, 1997) and mass wasting events present a significant volcanic hazard, and can also trigger hazardous laterally-directed explosions and devastating — both economically and in terms of loss of life — pyroclastic density currents (Cole et al., 2015; Glicken, 1996; Sparks et al., 2020; Voight et al., 1981). Indeed, partial flank collapses at about 200 volcanoes have resulted in at least 20,000 fatalities in the last 10,000 years (Siebert et al., 2010). Although about 52\% of these flank collapses are associated with magmatic eruptions, about $22 \%$ are associated with non-magmatic phreatic and/or hydrothermal eruptions (Siebert, 1984; Siebert et al., 1987, 2010). As a result, stability assessments at volcanoes are an essential component of volcano monitoring and volcanic hazard mitigation.

Hydrothermal alteration, common to many volcanoes worldwide, is often invoked as a mechanism that contributes significantly to volcano instability. Indeed, studies using geological evidence, geochemical or geophysical data, numerical modeling, laboratory experiments, or a combination of these approaches have highlighted that hydrothermal alteration has or can weaken a volcanic slope sufficiently to promote collapse (Ball et al., 2013, 2015, 2018; Cecchi

et al., 2004; del Potro and Hürlimann, 2009; Finn et al., 2018; John et al., 2008; López and Williams, 1993; Opfergelt et al., 2006; Reid et al., 2001; Rosas-Carbajal et al., 2016; Salaün et 
al., 2011; van Wyk de Vries et al., 2000; Voight et al., 2002; Watters et al., 2000). Fluid and pore fluid pressure re-distributions caused by alteration are also thought to promote instability (Ball et al., 2018; Day, 1996; Heap et al., 2021a; Reid, 2004) and erratic explosive behavior (de Moor et al., 2019; Heap et al., 2019; Mick et al., 2021).

Geological evidence is provided by the abundance of hydrothermally altered materials typically found in debris avalanche deposits resulting from partial flank collapse. For example, in their analysis of the 26 December 1997 partial edifice collapse at Soufrière Hills volcano (Montserrat, Eastern Caribbean), Voight et al. (2002) found varicolored, hydrothermallyaltered materials within the avalanche deposits, highlighting that alteration could have contributed to the collapse of the southern sector of the volcano. Avalanche deposits and material ejected during phreatic explosions at La Soufrière de Guadeloupe (Eastern Caribbean; France) were also found to contain various parts of the active and ancient hydrothermal systems of the volcano (Salaün et al., 2011). Debris avalanche deposits at Tutupaca volcano (Peru) also contain hydrothermally altered materials (Samaniego et al., 2015). Extensive fumarole activity and hydrothermal alteration on the unstable flanks of Casita volcano (Nicaragua) was documented by van Wyk de Vries et al. (2000), a volcano that experienced a partial flank collapse in 1998 with associated debris avalanches that killed about 2,500 people (Kerle and van Wyk de Vries, 2001; van Wyk de Vries et al., 2000). Opfergelt et al. (2006) further suggested that the presence of abundant smectite (up to $50 \mathrm{wt} . \%$ ) in the hydrothermally-altered core of Casita volcano contributed to slope instability by acting as a barrier to water infiltration thereby promoting fluid circulation along marked discontinuities, gradually decreasing the shear strength of the host-rock. Finally, more than 55 debris flows have originated from Mt Rainer (USA) in the Holocene, and hydrothermally derived clays have been found in some of the most widespread lahar deposits (Reid et al., 2001). 

techniques. For example, electrical tomography data exposed the extent of the hydrothermally altered zone, the location and geometry of low-strength detachment planes, and potential collapse volumes at La Soufrière de Guadeloupe (Rosas-Carbajal et al., 2016). Hyperspectral

122 remote sensing (Kereszturi et al., 2021) and helicopter electromagnetic and magnetic 123 measurements (Finn et al., 2018) have been used to map hydrothermal alteration zones to 124 inform slope stability modeling at Mt Ruapehu (New Zealand) and Mount Baker (USA), respectively, highlighting the most likely location of future collapses. Finally, geochemical data and modeling provided by López and Williams (1993) suggested that hydrothermal alteration along faults can create weak sliding planes that can facilitate slope failure.

129 alteration can influence volcano stability. For example, using analogue experiments in which sand-plaster mixtures and silicone were used to represent fresh and altered rock, respectively,

131 van Wyk de Vries et al. (2000) showed that a weak and ductile (hydrothermally altered) core 132 can reproduce the deformation structures observed at Casita volcano, suggesting that 133 hydrothermal alteration destabilized the volcano. Motivated by intensive alteration on the 134 flanks and summit of Mt Rainer, Reid et al. (2001) examined the influence of alteration on 135 volcano stability using a geotechnical method of 3D column limit-equilibrium slope stability 136 analysis. Using a best-estimate distribution of the alteration, and typical values of cohesion, 137 internal friction angle, and rock unit weight for fresh, lightly altered, and highly altered rocks, 138 Reid et al. (2001) concluded that steep slopes and large volumes of altered and weak rock can 139 promote potentially large gravitational failures.

140 Although these aforementioned studies, and others, have improved our understanding 141 of alteration-induced volcano instability, the shape and size of the alteration zones and/or the 142 geomechanical properties used in large-scale stability modeling are often poorly constrained or 
143 arbitrarily chosen. Indeed, there is a paucity of mechanical data for variably altered volcanic

144 rocks for use in large-scale numerical models designed to better understand flank stability. As 145 noted by Ball et al. (2018), the scarcity of rock physical and mechanical properties for altered

146 volcanic rocks limits the investigation of volcano stability using large-scale models. We present

147 here a multidisciplinary study in which we first provide physical and mechanical properties for 148 variably altered andesites from La Soufrière de Guadeloupe. We then assign laboratory-scale 149 and upscaled (i.e. modified to account for large-scale discontinuities that are not captured in 150 laboratory-scale samples) physical and mechanical properties to zones identified by a recent 151 electrical survey of the dome of La Soufrière de Guadeloupe (Rosas-Carbajal et al., 2016) and

152 perform large-scale numerical modeling to showcase the importance of hydrothermal alteration 153 on volcano stability. Finally, we combine recent muon tomography data (Rosas-Carbajal et al., 154 2017) with our laboratory data to create a 3D compressive strength map of the volcano. 155 Although we use La Soufrière de Guadeloupe as a case study, we consider our salient 156 conclusions relevant for andesitic stratovolcanoes worldwide.

\section{La Soufrière de Guadeloupe (Eastern Caribbean, France)}

La Soufrière de Guadeloupe (Figure 1a), henceforth called La Soufrière, is located on

160 the island of Guadeloupe in the Eastern Caribbean (Figure 1b) and is an archetype of the

161 hazardous andesitic volcanoes that occur in many subduction zones. The current lava dome

162 formed in $1530 \mathrm{CE}$ and, since $1635 \mathrm{CE}$, there have been six non-magmatic phreatic or

163 hydrothermal eruptions (Komorowski et al., 2005). The largest and most-recent eruption

164 occurred in 1976-1977. After months of seismic unrest, the volcano exploded suddenly and

165 without precursory signs in 1976-1977, resulting in a volcanic crisis that led to the evacuation

166 of about 70,000 people and serious socioeconomic consequences for the island (Feuillard et al.,

167 1983; Hincks et al., 2014; Komorowski et al., 2005, 2015). 
169 the restart of fumarolic and seismic activity (Komorowski et al., 2005) and, in April 2018, the 170 largest felt volcano-tectonic earthquake since the 1976-1977 crisis $\left(\mathrm{M}_{\mathrm{L}} 4.1\right.$ or $\mathrm{M}_{\mathrm{W}} 3.7$; Moretti 171 et al., 2020). The 2018 episode of accelerated unrest was interpreted as a failed phreatic eruption 172 and raised serious concerns for the stability of the southwest flank of the dome, which shows 173 the largest displacements (up to $9 \mathrm{~mm} /$ year towards the southwest) over the last 20 years 174 (Moretti et al., 2020). The main features of the ongoing unrest include the continuous expansion of the outgassing area on top of the lava dome and the appearance of new steam-dominated fumaroles in July 2014 and February 2016 that are characterized by a deep magmatic gas 177 component (Brombach et al., 2000; Moretti et al., 2020; Villemant et al., 2014). Such expansion 178 was accompanied by an increase in the heat output from the entire dome, which evolved from 1.2 MW in 2010 to 7.6 MW in 2020 (Jessop et al., 2021). This increase in heat output is of 180 great concern for La Soufrière as it has been recently demonstrated that volcanoes with a high 181 heat flux are more likely to experience magmatic or phreatic eruptions (Girona et al., 2021). 182 High-flow rate thermal acid sulfate-chloride springs, associated with degassing of the 183 underlying magmatic body, are observed on the slopes and at the base of the dome and supply 184 hot acid fluids and $\mathrm{CO}_{2}$, but also $\mathrm{SO}_{2}, \mathrm{H}_{2} \mathrm{~S}, \mathrm{HCl}$, and $\mathrm{HF}$, to the above hydrothermal system 185 (Villemant et al., 2005; 2014). These acidic fluids are (1) transferred through the dome and feed 186 the steam-rich summit fumaroles and (2) circulate through the dome structure along listric, 187 concave-upward structural discontinuities that drain to the southwest (Brombach et al., 2000; 188 Rosas-Carbajal et al., 2016; Salaün et al., 2011; Villemant et al., 2014). Evidence for the 189 preferential circulation of acidic thermal fluids along these structures is provided by the 3D 190 geometry of thermal springs (Moretti et al., 2020; Villemant et al., 2005) and geophysical 191 imaging (Bouligand et al., 2016; Brothelande et al., 2014; Nicollin et al., 2006; Rosas-Carbajal 192 et al., 2016). The shallow hydrothermal system is considered responsible for the recent 
193 observed shallow deformation and seismic activity (at depths at or above sea level, with

194 magnitudes less than one) (Moretti et al., 2020). Indeed, the monthly bulletins from the

195 observatory (Observatoire Volcanologique et Sismologique de Guadeloupe, Institut de

196 Physique du Globe de Paris (OVSG-IPGP), 1999-2021; available at

197 http://www.ipgp.fr/fr/ovsg/bulletins-mensuels-de-lovsg) document hundreds of shallow, low-

198 magnitude $(\mathrm{M}<1)$ earthquakes each month. Deeper and higher magnitude off-axis seismic

199 activity are thought to be related to increases in pore pressure in response to the pulsatory arrival

200 of hot magmatic fluids along the larger faults that cut the dome (Moretti et al., 2020).

201 The recent unrest, suggesting that La Soufrière is undergoing a renewed period of 202 structural and chemical weakening, raises concern for the stability of the volcano. Indeed, the 203 most-recent unrest and instability at La Soufrière was associated with hydrothermal activity. 204 For example, the materials ejected during the explosive hydrothermal eruption of 1976-1977 205 were largely hydrothermally altered (Feuillard et al., 1983) and geological studies have also 206 shown that La Soufrière has an exceptional record of partial edifice collapse (at least eight 207 collapses in the past 9,150 years) that have produced extensive debris avalanche deposits 208 dominantly composed of hydrothermally altered materials (Boudon et al., 1987; Komorowski 209 et al., 2005; Le Friant et al., 2006; Peruzzetto et al., 2019; Rosas-Carbajal et al., 2016; Salaün 210 et al., 2011). The simulations of Le Friant et al. (2006) and Peruzzetto et al. (2019) suggest that 211 the northern and eastern parts of the town of Saint Claude could be impacted by small-volume 212 partial dome collapses and that, in the worst-case scenario of a major dome collapse, a large 213 part of Basse-Terre could be affected. As a result, not only is La Soufrière an ideal natural 214 laboratory to study the influence of hydrothermal alteration on volcano stability, but such a 215 study is also timely because of the ongoing, and increasing, unrest at the volcano. 

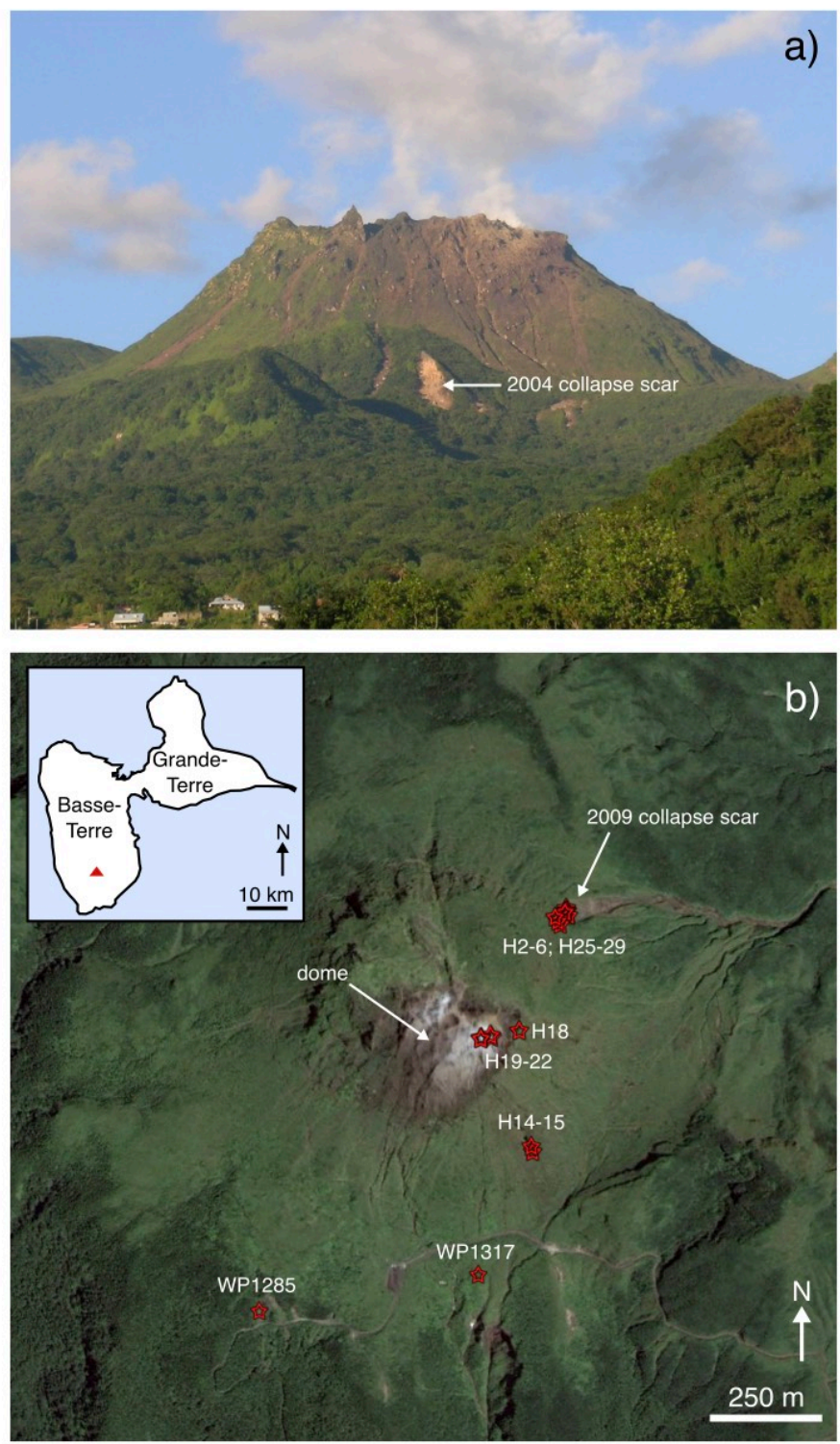

218 Figure 1. (a) Photograph of La Soufrière de Guadeloupe (Eastern Caribbean, France). This

219 photograph also shows the collapse scar (indicated by the white arrow) triggered by the 21

220 November 2004 Les Saintes magnitude Mw 6.3 regional earthquake (Feuillet et al., 2011). (b)

221 Map of La Soufrière de Guadeloupe (taken from Google Maps ${ }^{\circledR}$ ) showing the sampling 222 locations for the 17 blocks acquired for this study. This image also shows the location of the dome and the 2009 collapse scar (indicated by white arrows). Inset shows a map of triangle. 


\section{Materials and Methods}

A total of 17 blocks were collected from La Soufrière during a field campaign in 2019 (sampling locations shown as red stars in Figure 1b). Our aim was to sample a range of materials from different locations on the volcano that best represent the variability in porosity and hydrothermal alteration of the rocks forming the edifice. A large proportion of the blocks (eight 232 out of 17) were collected from the collapse scar of the 19 November 2009 landslide, triggered 233 by extreme rainfall (Moretti et al., 2020; Peruzzetto et al., 2019), which was seen as an opportunity to sample blocks that are more representative of the interior of the volcano.

Eight blocks were taken from the collapse scar of the 2009 landslide (H2A, H2B, H3, H4A, H5A, H6, H25, and H29), one block was taken from the collapse scar of the landslide triggered by the 21 November 2004 Les Saintes magnitude Mw 6.3 regional earthquake (Feuillet et al., 2011; Figure 1b) (WP1285), two blocks were taken from the West wall of the fault "Faille 30 août" (H14 and H15), and one block, a volcanic bomb from the 1976-1977 eruption, was taken from the roof of a small disused thermal bathhouse to the South of the dome (WP1317). The remaining samples were taken from the dome: one block was taken from the "Lacroix Supérieur" outgassing fracture (H18), and four blocks were taken from the lava spines of the 1530 CE dome: two blocks from "Cratère Sud Central" (H19 and H20) and two blocks from an adjacent site (H21 and H22). Site descriptions and Global Positioning System (GPS) coordinates are available for each block in the Supplementary Information.

247 then cut and precision-ground to a nominal length of $40 \mathrm{~mm}$. The samples were washed and 248 then dried in a vacuum-oven at $40{ }^{\circ} \mathrm{C}$ for at least $48 \mathrm{~h}$. The connected porosity of each sample 249 was calculated using the bulk sample volume and the skeletal (solid) sample volume measured 250 by a helium pycnometer. Dry and wet bulk sample densities were calculated using the bulk 251 sample volume and the dry and wet mass, respectively. Polished thin sections were prepared 
252 from offcuts of the samples for microstructural analysis, performed using a Tescan Vega 2

253 XMU scanning electron microscope (SEM). The mineral content of the 17 blocks was analyzed

254 and quantified using X-ray powder diffraction (XRPD) on powdered offcuts of the samples,

255 assisted by Raman spectroscopy on the prepared thin sections (see Supplementary Information 256 for more details).

257 Dry uniaxial compressive strength was measured on oven-dry samples from all 17 258 blocks in a uniaxial load frame. Samples were deformed under ambient laboratory pressure and 259 temperature at a constant axial strain rate of $10^{-5} \mathrm{~s}^{-1}$ until macroscopic failure. The static 260 Young's modulus was determined from the elastic portion of the uniaxial stress-strain curves 261 (Heap et al., 2020a). Triaxial compression experiments were performed on blocks selected to 262 best represent the variability in observed alteration (samples $\mathrm{H} 2 \mathrm{~B}, \mathrm{H} 3$, and $\mathrm{H} 18$ ). These samples 263 were vacuum-saturated in deionized water, inserted into a rubber jacket, placed inside a 264 pressure vessel, and then taken to the target confining (from 10.5 to $25 \mathrm{MPa}$ ) and pore fluid pressures (10 MPa for all experiments) using servo-controlled pumps. Samples were deformed under ambient laboratory temperature at a constant axial strain rate of $10^{-5} \mathrm{~s}^{-1}$ until either 267 macroscopic failure (for brittle experiments) or until 3\% axial strain (for ductile experiments). 268 The triaxial apparatus was also used to measure the water-saturated uniaxial compressive 269 strength of samples H2B, H3, and H18. For both uniaxial and triaxial experiments, axial 270 displacement and axial load were measured using a linear variable differential transducer and a 271 load cell, respectively. Axial displacement (minus the displacement accumulated within the 272 load chain) and axial load were converted to axial strain and axial stress using the sample 273 dimensions. Here, we define the effective pressure, $P_{e f f}$, as the confining pressure, $P_{c}$, minus 274 the pore fluid pressure, $P_{p}$. We adopt the convention that compressive stresses and strains are 275 positive. 


\section{Results}

4.1 Microstructure, mineralogy, and alteration

The mineral contents for each of the 17 blocks are given in Table 1, and Figure 2 shows

280 backscattered SEM images of three blocks selected to represent the range of alteration intensity

281 (defined by their percentage of secondary minerals) observed in the rocks collected for this 282 study (relatively unaltered - H18; moderately altered - H3; and highly altered - H2B). SEM 283 images of all the blocks are available in the Supplementary Information. All of the andesite 284 blocks are characterized by a porphyritic texture comprising phenocrysts of dominantly 285 plagioclase and pyroxene (and high-density oxides) within a crystallized groundmass (Figure 286 2). All of the samples also contain secondary minerals, including silica polymorphs (quartz, 287 cristobalite, tridymite, and opal-A), hematite, pyrite, alunite or natroalunite, gypsum, kaolinite, 288 and talc (Table 1). Plagioclase phenocrysts are often pervasively altered and partially replaced 289 by kaolinite (e.g., Figure 2c) or opal-A. Secondary minerals (natroalunite, alunite, cristobalite, 290 tridymite, pyrite, and kaolinite) are also found precipitated within pores and microcracks (see 291 Supplementary Information for additional SEM images). 

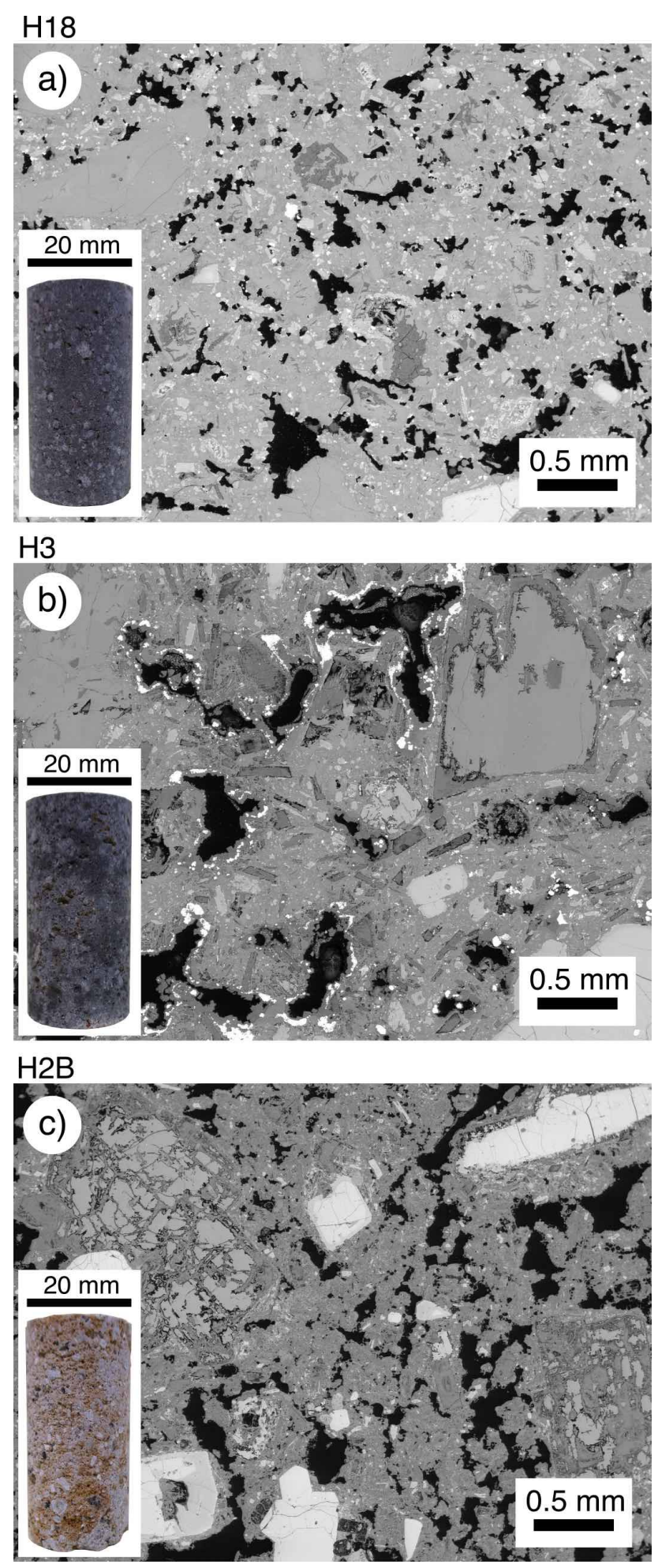

Figure 2. Backscattered scanning electron microscope images of three andesites from La

295 Soufrière de Guadeloupe (Eastern Caribbean, France) selected to represent the range of

296 observed alteration: (a) relatively unaltered - H18, (b) moderately altered - H3, and (c) highly 
altered - H2B. Black - porosity; grayscale - rock groundmass. Insets show photographs of the $20 \mathrm{~mm}$-diameter cylindrical samples.

\begin{tabular}{|c|c|c|c|c|c|c|c|c|c|c|c|c|c|c|c|c|c|}
\hline Mineral & H2A & H2B & H3 & H4A & H5A & H6 & H14 & H15 & H18 & H19 & H20 & H21 & H22 & $\mathbf{H 2 5}$ & $\mathbf{H 2 9}$ & WP1285 & WP1317 \\
\hline Plagioclase & 56.7 & 12.3 & 46.6 & 23.3 & 41.3 & 30.0 & 60.7 & 22.5 & 61.2 & 22.0 & 28.7 & 24.2 & 59.5 & 38.7 & 62.4 & 64.7 & 61.6 \\
\hline Clinopyroxene & 8.7 & 3.4 & 5.6 & 4.9 & 5.2 & 6.4 & 6.3 & 7.3 & 8.4 & 5.0 & 8.9 & 12.4 & 8.9 & 5.3 & 7.8 & 5.2 & 5.9 \\
\hline Orthopyroxene & 10.8 & 9.5 & 11.8 & 11.8 & 11.1 & 10.8 & 8.6 & 9.2 & 12.2 & 10.2 & 15.0 & 19.3 & 13.6 & 10.2 & 11.2 & 13.2 & 15.6 \\
\hline (Ti-) Magnetite & 0.7 & - & 0.8 & - & - & - & 0.8 & - & 2.9 & - & 2.4 & 3.1 & 0.8 & - & 2.7 & 3.5 & 0.7 \\
\hline Quartz* & 1.0 & 0.5 & 0.6 & 0.6 & 0.5 & 0.5 & 1.7 & 0.7 & 0.7 & 1.7 & 0.3 & 0.2 & 0.6 & 0.3 & 0.4 & 0.2 & 0.7 \\
\hline Cristobalite* & 11.3 & 12.8 & 10.6 & 11.8 & 13.0 & 11.1 & 13.5 & 10.2 & 11.7 & 9.5 & 11.4 & 11.7 & 10.6 & 9.8 & 12.4 & - & - \\
\hline Tridymite* & - & - & - & - & - & - & - & 0.7 & - & - & - & - & - & - & - & 13.2 & 13.2 \\
\hline Hematite* & - & - & - & - & - & - & 3.4 & - & 2.8 & 2.4 & - & - & - & - & 3.1 & - & - \\
\hline Pyrite* & 3.5 & - & 3.8 & 2.3 & - & - & - & - & - & - & - & 0.4 & 3.1 & 0.6 & - & - & - \\
\hline Alunite* & - & - & - & - & - & - & - & - & - & - & - & - & - & - & - & - & 2.4 \\
\hline Na-Alunite* & 1.4 & 1.6 & 2.8 & 1.3 & 5.4 & 5.1 & 5.1 & 15.0 & - & 14.2 & 0.5 & 0.5 & - & 9.8 & - & - & - \\
\hline Gypsum* & - & - & - & 0.7 & - & - & - & - & - & - & 0.8 & 1.2 & - & - & - & - & - \\
\hline Kaolinite* & 6 & 59.7 & 17.4 & 43.3 & 23.5 & 36.0 & $<1$ & 34.3 & - & 2.0 & 2.0 & 2.0 & $<1$ & 25.3 & - & - & - \\
\hline Talc* & - & - & - & - & $\begin{array}{l}- \\
-\end{array}$ & - & - & - & - & - & - & - & 2.9 & - & - & - & - \\
\hline Opal-A* & - & - & - & - & - & - & - & - & - & 33.0 & 30.0 & 25.0 & - & - & 10.0 & - & - \\
\hline
\end{tabular}

Table 1. Mineral contents, measured by X-ray powder diffraction and refined using Raman spectroscopy and optical microscopy, of the 17 blocks collected for this study (sampling

\subsection{Mechanical data}

mineral.

Representative uniaxial stress-strain curves for selected samples are shown in Figure

3a. Stress is first a non-linearly increasing function of strain, often attributed to the closure of pre-existing microcracks. This stage is followed by a quasi-linear elastic stage. In the next stage, stress is a non-linearly decreasing function of strain, a result of the initiation, propagation, and

311 coalescence of microcracks. Finally, a stress drop signals the formation of a macroscopic shear

312 fracture. Uniaxial compressive strength and Young's modulus are plotted as a function of 313 connected porosity in Figures $3 b$ and 3c, respectively (data available in Table 2). We first note 
314 that the connected porosity of our samples varies from 0.12 to 0.43 . The uniaxial compressive

315 strength and Young's modulus of our sample suite varies from $\sim 3.5$ to $\sim 150 \mathrm{MPa}$ and from $\sim 1$

316 to $\sim 43 \mathrm{GPa}$, respectively (Figure 3 ). Our data show that uniaxial compressive strength and

317 Young's modulus both decrease as a function of increasing porosity (Figure 3).
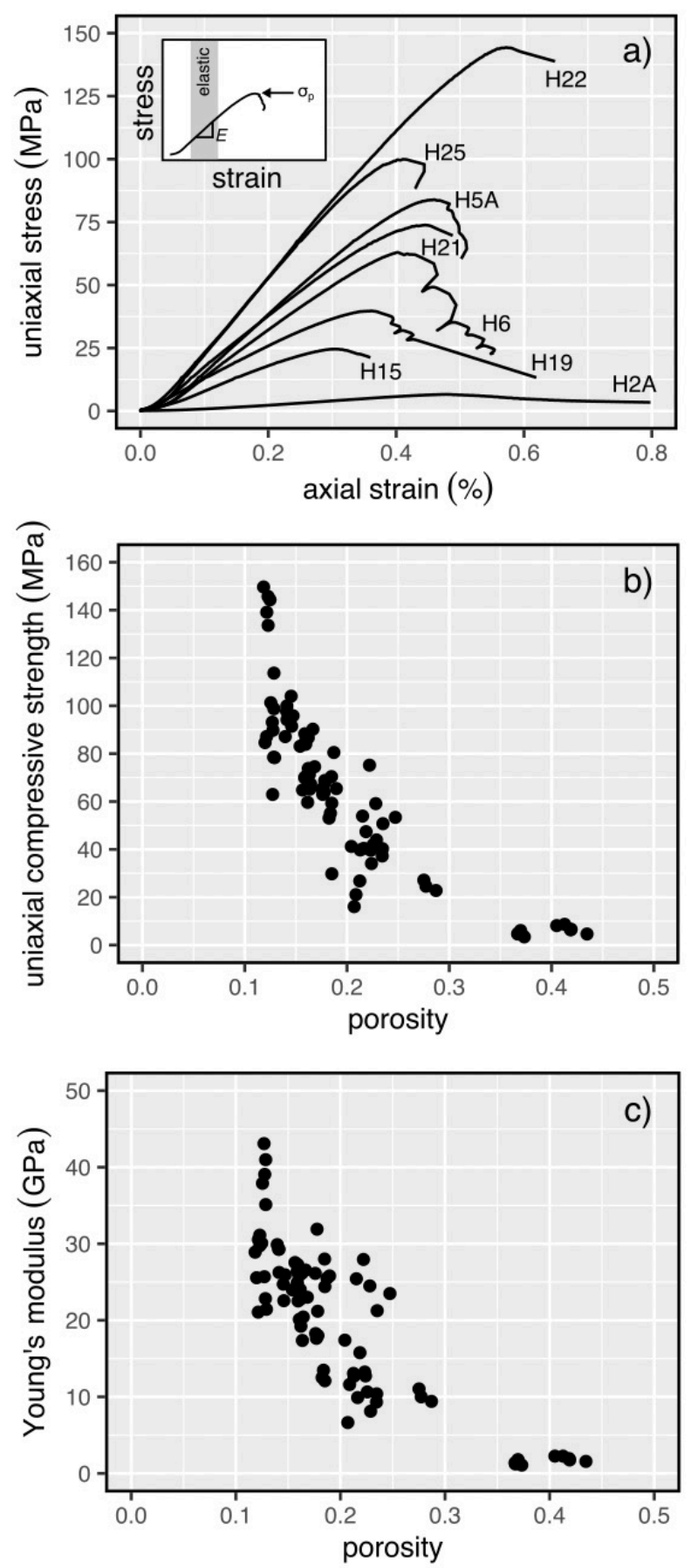
Figure 3. (a) Representative stress-strain curves for selected andesite samples from La

321 Soufrière de Guadeloupe (Eastern Caribbean, France). Inset shows an isolated curve

322 indicating from where the Young's modulus (the slope of the stress-strain curve), E, was

323 determined (the quasi-linear elastic stage is indicated by the gray zone). Also labeled is the

324 uniaxial compressive strength, $\sigma_{p}$, which is the maximum axial stress the sample attained

325 prior to macroscopic failure (signaled by the stress drop). Uniaxial compressive strength (b)

326 and Young's modulus (c) as a function of connected porosity (data available in Table 2).

\begin{tabular}{|c|c|c|c|c|}
\hline Sample & $\begin{array}{c}\text { Connected } \\
\text { porosity }\end{array}$ & $\begin{array}{c}\text { Uniaxial } \\
\text { compressive } \\
\text { strength (MPa) }\end{array}$ & $\begin{array}{c}\text { Young's modulus } \\
\text { (GPa) }\end{array}$ & $\begin{array}{c}\text { Percentage of } \\
\text { secondary } \\
\text { minerals }\end{array}$ \\
\hline H2A_2 & 0.18 & 63.7 & 31.9 & 23.2 \\
\hline H2A_5 & 0.19 & 80.5 & 25.5 & 23.2 \\
\hline H2A_6 & 0.19 & 65.4 & 25.8 & 23.2 \\
\hline H2A_11 & 0.19 & 59.3 & 24.4 & 23.2 \\
\hline H2A_12 & 0.18 & 70.4 & 28.0 & 23.2 \\
\hline H2B_3 & 0.42 & 6.6 & 1.8 & 74.6 \\
\hline H2B_10 & 0.42 & 6.4 & 1.9 & 74.6 \\
\hline H2B_11 & 0.41 & 8.7 & 2.3 & 74.6 \\
\hline H2B_12 & 0.41 & 8.1 & 2.3 & 74.6 \\
\hline H2B_15 & 0.43 & 4.6 & 1.6 & 74.6 \\
\hline H3_3 & 0.16 & 70.3 & 27.3 & 35.2 \\
\hline H3_7 & 0.16 & 69.9 & 24.9 & 35.2 \\
\hline H3_8 & 0.16 & 64.8 & 27.5 & 35.2 \\
\hline H3_11 & 0.16 & 59.7 & 24.0 & 35.2 \\
\hline H3_13 & 0.16 & 71.2 & 26.2 & 35.2 \\
\hline H4A_2 & 0.23 & 40.3 & 10.4 & 60.0 \\
\hline H4A_4 & 0.23 & 42.0 & 10.6 & 60.0 \\
\hline H4A_6 & 0.23 & 43.9 & 8.1 & 60.0 \\
\hline H4A_8 & 0.23 & 37.2 & 9.3 & 60.0 \\
\hline H4A_9 & 0.22 & 40.4 & 9.9 & 60.0 \\
\hline H5A_2 & 0.16 & 88.3 & 26.4 & 42.4 \\
\hline H5A_3 & 0.16 & 86.6 & 22.8 & 42.4 \\
\hline H5A_5 & 0.16 & 83.9 & 22.5 & 42.4 \\
\hline H5A_8 & 0.18 & 68.8 & 21.2 & 42.4 \\
\hline H5A_10 & 0.17 & 74.5 & 23.0 & 42.4 \\
\hline H6_6 & 0.18 & 55.1 & 13.5 & 52.7 \\
\hline H6_9 & 0.18 & 68.0 & 18.0 & 52.7 \\
\hline H6_9 & 0.18 & 53.0 & 12.5 & 52.7 \\
\hline H6_12 & 0.18 & 64.2 & 17.6 & 52.7 \\
\hline H6_13 & 0.18 & 63.0 & 18.3 & 52.7 \\
\hline H14_2 & 0.18 & 65.4 & 26.1 & 23.7 \\
\hline
\end{tabular}




\begin{tabular}{|c|c|c|c|c|}
\hline H14_3 & 0.21 & 21.1 & 11.6 & 23.7 \\
\hline H14_5 & 0.21 & 26.8 & 13.1 & 23.7 \\
\hline H14_6 & 0.19 & 29.8 & 12.1 & 23.7 \\
\hline H14 10 & 0.21 & 16.1 & 6.6 & 23.7 \\
\hline H15_3 & 0.28 & 24.6 & 10.0 & 60.9 \\
\hline H15 4 & 0.28 & 27.1 & 11.0 & 60.9 \\
\hline H15_5 & 0.29 & 22.8 & 9.4 & 60.9 \\
\hline H18_3 & 0.13 & 101.3 & 37.9 & 15.2 \\
\hline H18_4 & 0.13 & 89.8 & 39.1 & 15.2 \\
\hline H18 5 & 0.13 & 98.8 & 41.0 & 15.2 \\
\hline H18_6 & 0.13 & 93.2 & 43.1 & 15.2 \\
\hline H18_7 & 0.13 & 113.7 & 35.1 & 15.2 \\
\hline H19_3 & 0.21 & 39.7 & 12.7 & 62.8 \\
\hline H19_8 & 0.22 & 47.4 & 15.8 & 62.8 \\
\hline H19_9 & 0.22 & 34.1 & 12.7 & 62.8 \\
\hline H19_12 & 0.20 & 41.2 & 17.4 & 62.8 \\
\hline H19_15 & 0.22 & 39.6 & 13.2 & 62.8 \\
\hline H20_2 & 0.37 & 4.8 & 1.2 & 45.0 \\
\hline H20_3 & 0.37 & 4.4 & 1.3 & 45.0 \\
\hline H20_7 & 0.37 & 4.6 & 1.4 & 45.0 \\
\hline H20_8 & 0.37 & 6.1 & 1.8 & 45.0 \\
\hline H20_10 & 0.37 & 3.4 & 1.1 & 45.0 \\
\hline H21_3 & 0.17 & 90.2 & 26.6 & 41.0 \\
\hline H21_8 & 0.16 & 65.2 & 17.4 & 41.0 \\
\hline H21_11 & 0.16 & 86.9 & 25.8 & 41.0 \\
\hline $\mathrm{H} 21 \_12$ & 0.16 & 73.8 & 19.2 & 41.0 \\
\hline H21_13 & 0.16 & 87.2 & 20.1 & 41.0 \\
\hline H22_2 & 0.12 & 145.7 & 29.7 & 17.2 \\
\hline H22_3 & 0.12 & 144.3 & 30.1 & 17.2 \\
\hline H22_4 & 0.12 & 139.1 & 30.5 & 17.2 \\
\hline H22_5 & 0.12 & 149.7 & 28.9 & 17.2 \\
\hline H22_6 & 0.12 & 133.6 & 31.1 & 17.2 \\
\hline $\mathrm{H} 25 \_2$ & 0.14 & 99.9 & 29.3 & 45.8 \\
\hline $\mathrm{H} 25 \_4$ & 0.14 & 97.7 & 29.3 & 45.8 \\
\hline H25_5 & 0.14 & 94.2 & 26.2 & 45.8 \\
\hline H25_9 & 0.14 & 87.1 & 29.9 & 45.8 \\
\hline H25_12 & 0.15 & 83.1 & 24.0 & 45.8 \\
\hline H29_2 & 0.22 & 53.9 & 25.4 & 25.9 \\
\hline H29_8 & 0.23 & 59.1 & 24.5 & 25.9 \\
\hline H29_9 & 0.22 & 75.2 & 27.9 & 25.9 \\
\hline H29_12 & 0.25 & 53.4 & 23.5 & 25.9 \\
\hline H29_16 & 0.24 & 50.7 & 21.3 & 25.9 \\
\hline WP1285_2 & 0.13 & 78.5 & 22.8 & 13.4 \\
\hline WP1285_8 & 0.13 & 63.0 & 25.7 & 13.4 \\
\hline WP1285_10 & 0.13 & 78.3 & 21.4 & 13.4 \\
\hline WP1285_11 & 0.12 & 87.2 & 21.1 & 13.4 \\
\hline WP1285_15 & 0.12 & 84.6 & 25.6 & 13.4 \\
\hline WP1317_2 & 0.16 & 67.3 & 20.4 & 16.3 \\
\hline WP1317_6 & 0.16 & 84.5 & 24.7 & 16.3 \\
\hline WP1317_7 & 0.15 & 91.5 & 22.6 & 16.3 \\
\hline
\end{tabular}




\begin{tabular}{|c|c|c|c|c|}
\hline WP1317_8 & 0.15 & 95.8 & 25.9 & 16.3 \\
\hline WP1317_12 & 0.15 & 104.0 & 24.7 & 16.3 \\
\hline
\end{tabular}

328

Table 2. Connected porosity, uniaxial compressive strength, Young's modulus, and the percentage of secondary minerals (i.e. alteration) for the samples prepared for this study. Sample locations are provided in Figure 1b (site descriptions and GPS coordinates are available in the Supplementary Information). relatively unaltered block (H18), a moderately altered block (H3), and a very altered block (H2B). The microstructure of these samples is provided in Figure 2 and their mineral componentry in Table 1. The percentages of secondary minerals (determined using the XRPD data; Table 1) for these rocks are 15.2, 35.2, and 74.6\%, respectively. Triaxial experiments were performed on $\mathrm{H} 18$ samples at effective pressures of $0,2.5,5,10$, and $15 \mathrm{MPa}$ (Figure 4a), on $\mathrm{H} 3$ samples at effective pressures of $0,2.5,5$, and $7.5 \mathrm{MPa}$ (Figure $4 \mathrm{~b}$ ), and on $\mathrm{H} 2 \mathrm{~B}$ samples at effective pressures of $0,0.5,1$, and $2 \mathrm{MPa}$ (Figure 4c) (data available in Table 3). Different effective pressures were chosen for the different samples in an attempt to ensure the brittle behavior required to calculate the cohesion and angle of internal friction. Blocks H18 (Figure 4a) and H3 (Figure 4b) were brittle over the chosen range of effective pressures. The compressive strength of blocks H18 and H3 increased as a function of increasing effective pressure: H18 increased from 65.4 to $143.8 \mathrm{MPa}$ and $\mathrm{H} 3$ increased from 31.5 to $54.8 \mathrm{MPa}$ as effective pressure was increased from 0 to 15 and $7.5 \mathrm{MPa}$, respectively (Figure 4). The stressstrain curves for block H2B are very different to those for blocks H18 and H3 (Figure 4). Subtle strain softening associated with brittle behavior was observed for the experiments performed at effective pressures of 0 and $0.5 \mathrm{MPa}$, but no strain softening was seen at 1 and $2 \mathrm{MPa}$, suggestive of ductile behavior (Figure 4c). 
353 (excluding the two ductile H2B experiments), necessary for the large-scale numerical modeling, 354 were $14.8 \mathrm{MPa}$ and $46.7^{\circ}$ for $\mathrm{H} 18,7.1 \mathrm{MPa}$ and $37.7^{\circ}$ for $\mathrm{H} 3$, and $0.4 \mathrm{MPa}$ and $42.5^{\circ}$ for $\mathrm{H} 2 \mathrm{~B}$, 355 respectively (Figure 4). The method for determining these values is explained in the 356 Supplementary Information. 

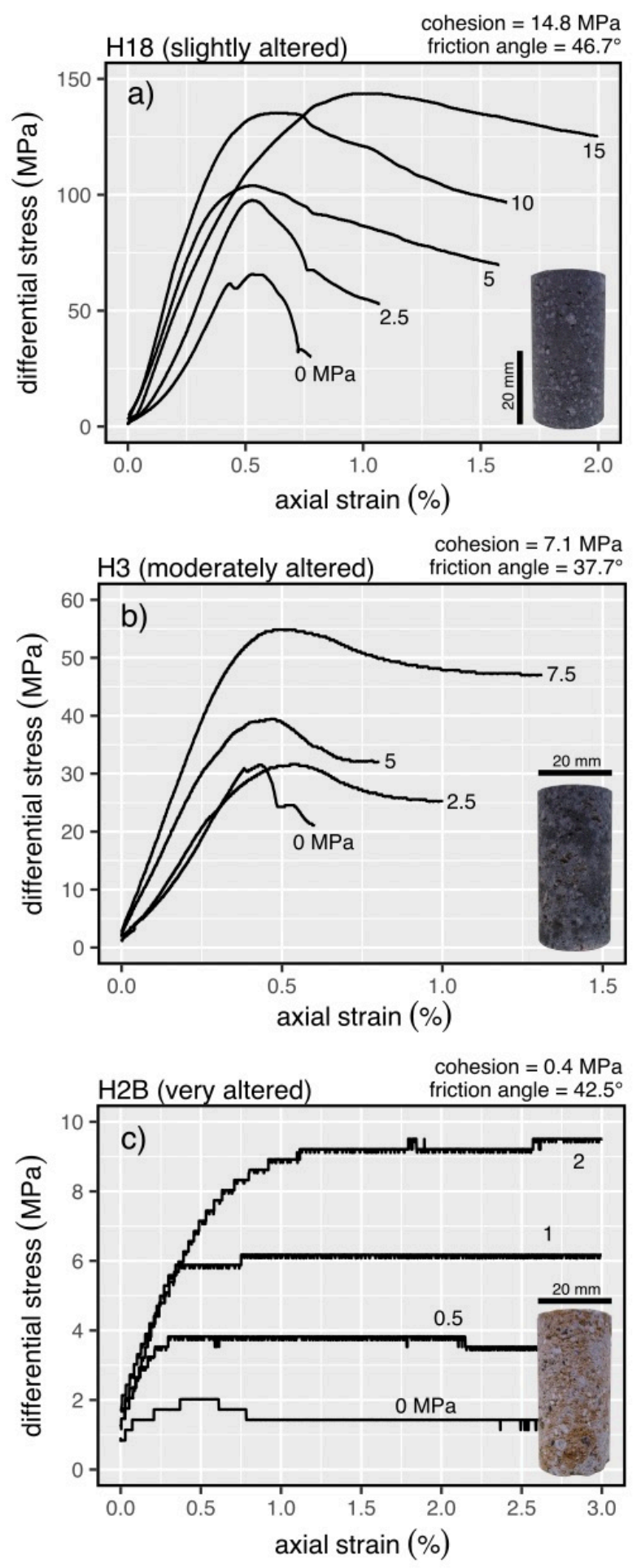

359 Figure 4. Stress-strain curves for andesites from La Soufrière de Guadeloupe (Eastern 360 Caribbean, France) deformed under different effective pressures (given by the number 361 adjacent to each curve). (a) Relatively unaltered sample H18. (b) Moderately altered sample 362 H3. (c) Very altered sample H2B. Differential stress is the axial stress minus the confining 
pressure. Insets show photographs of the $20 \mathrm{~mm}$-diameter cylindrical samples. The values of cohesion and internal friction angle, calculated using these data, are also provided for each of the three rocks.

\begin{tabular}{|c|c|c|c|c|c|c|}
\hline Sample & $\begin{array}{c}\text { Connected } \\
\text { porosity }\end{array}$ & $\begin{array}{c}\text { Percentage } \\
\text { of } \\
\text { secondary } \\
\text { minerals }\end{array}$ & $\begin{array}{c}\text { Pore fluid } \\
\text { pressure } \\
\text { (MPa) }\end{array}$ & $\begin{array}{c}\text { Confining } \\
\text { pressure } \\
\text { (MPa) }\end{array}$ & $\begin{array}{c}\text { Effective } \\
\text { pressure } \\
\text { (MPa) }\end{array}$ & $\begin{array}{c}\text { Peak } \\
\text { differential } \\
\text { stress (MPa) }\end{array}$ \\
\hline H18_11 & 0.13 & 15.2 & $0($ wet) & 0 & 0 & 65.7 \\
\hline H18_10 & 0.14 & 15.2 & 10 & 12.5 & 2.5 & 97.7 \\
\hline H18_2 & 0.12 & 15.2 & 10 & 15 & 5 & 104.0 \\
\hline H18_8 & 0.12 & 15.2 & 10 & 20 & 10 & 135.2 \\
\hline H3_14 & 0.16 & 35.2 & $0($ wet) & 0 & 0 & 31.5 \\
\hline H3_12 & 0.15 & 35.2 & 10 & 12.5 & 2.5 & 31.7 \\
\hline H3_4 & 0.15 & 35.2 & 10 & 15 & 5 & 39.4 \\
\hline H3_5 & 0.16 & 35.2 & 10 & 17.5 & 7.5 & 54.9 \\
\hline H2B_7 & 0.44 & 74.6 & $0(w e t)$ & 0 & 0 & 2.0 \\
\hline H2B_8 & 0.44 & 74.6 & 10 & 10.5 & 0.5 & 3.8 \\
\hline H2B_6 & 0.39 & 74.6 & 10 & 11 & 1 & - \\
\hline H2B_5 & 0.38 & 74.6 & 10 & 12 & 2 & - \\
\hline
\end{tabular}

Table 3. Experimental summary for the triaxial deformation experiments (and wet uniaxial experiments) performed on relatively unaltered (H18), moderately altered (H3), and very altered (H2B) andesites from La Soufrière de Guadeloupe (Eastern Caribbean, France). Sample locations are provided in Figure 1b (site descriptions and GPS coordinates are available in the Supplementary Information) and microstructural images are provided in

\section{Discussion}

\section{5.1 Hydrothermal alteration and mineral precipitation}

Figure 2.

Volcanic andesitic systems discharging acid-chloride-sulfate hydrothermal fluids (Browne, 1978; Ellis and Mahon, 1977; Taran and Kalacheva, 2020) are typically characterized 
of time available for neutralization (Taran and Kalacheva, 2020), or intermediate to advanced

381 argillic alteration in zones where fluids can circulate. The samples measured for this study were sourced from (1) zones proximal to summit fumarolic vents that tap the central zone characterized by the rapid ascent of steam separated from a boiling hydrothermal aquifer (Brombach et al., 2000; Moretti et al., 2020) (e.g., H18-22; Table 1) and (2) from zones far from currently active fumarolic zones, where the shallow groundwaters are heated via conduction and mixed with $\mathrm{Na}-\mathrm{Cl}$ liquids from the hydrothermal aquifer (Brombach et al., 2000; Villemant et al., 2014) (e.g., those sampled from the collapse scar of the 2009 landslide: H2A, H2B, H3, H4A, H5A, H6, H25, and H29; Table 1) (Figure 1b).

The secondary mineral assemblage in our samples (Table 1) is essentially the same as 390 that found in the debris avalanche deposits to the southwest of La Soufrière (Salaün et al., 2011).

391 However, the debris-avalanche deposits investigated by Salaün et al. (2011) contain abundant 392 smectite, whereas the samples collected for this study contain kaolinite and no smectite (Table

393 1). The presence of kaolinite, a key mineral in the argillic alteration facies, typically indicates 394 fluid-rock interaction at relatively low fluid temperatures $\left(<150-200{ }^{\circ} \mathrm{C}\right)$ and a $\mathrm{pH}$ of $\sim 4.5-6$ 395 (Fulignati, 2020; Inoue, 1995), but can also occur in the advanced argillic alteration facies (pH $396<3$; temperatures up to about $300{ }^{\circ} \mathrm{C}$ ). The altered samples analyzed in this study therefore 397 represent a more advanced stage of hydrolysis reactions than the smectite-bearing products 398 from the Holocene debris-avalanche deposits described in Salaün et al. (2011), indicating that 399 the rocks analyzed here were altered by hydrothermal fluids with a higher $\mathrm{H}^{+}$activity that led 400 to complete alkali leaching.

401 The most abundant secondary minerals are cristobalite, amorphous silica, natroalunite, 402 and kaolinite (Table 1). Cristobalite is a silica polymorph stable at low-pressure and high403 temperature in its cubic $\beta$-form (Schipper et al., 2020). Because it is kinetically favored, 404 metastable cristobalite is commonly found in preference to quartz in lava domes, where it 
precipitates from a vapor-phase enriched in magmatic components or results from groundmass

406 devitrification (Horwell et al., 2013; Martel et al., 2021; Schipper et al., 2020). Our samples

407 contain tetragonal $\alpha$-cristobalite, suggesting a final temperature lower than $240{ }^{\circ} \mathrm{C}$, the nominal

408 temperature for the transition from $\beta$ - to $\alpha$-cristobalite (Damby et al., 2014). Schipper et al.

409 (2020) identified a lower and broader range for the $\beta-\alpha$ transition in volcanic cristobalites

$410\left(\sim 150-200{ }^{\circ} \mathrm{C}\right)$, which overlaps with the temperature interval inferred by the presence of

411 kaolinite. The cristobalite in the studied samples precipitated onto pore walls (see Figure 2 and

412 the Supplementary Information) and so we consider that it predominately formed by vapor

413 deposition. Amorphous silica (opal-A) partially to completely replaced the plagioclase

414 phenocrysts (see Figure 2 and the Supplementary Information), as often observed in acid-sulfate

415 alteration zones (McCollom et al., 2013).

416 Alunite is a characteristic family of sulfate minerals produced by hypogene magmatic-

417 hydrothermal and steam-heated alteration or supergene processes (Rye et al., 1992). As such it

418 is commonly found in the alteration products of rhyolitic to andesitic rock compositions,

419 including surficial solfataric or acid hot spring environments. Alunite and natroalunite are the

420 two most common minerals of the alunite group (Stoffregen et al., 2000). Only the volcanic

421 bomb from the 1976-1977 eruption (sample WP1317) contains alunite, whereas natroalunite is

422 commonly observed (Table 1). Natroalunite is the high temperature end-member of the alunite

423 group and typically forms at $200-350{ }^{\circ} \mathrm{C}$, but is also stable at $380-450{ }^{\circ} \mathrm{C}$ (Henley and Berger,

424 2011; Meyer and Hemley 1967). Natroalunite precipitates from an acidic $(\mathrm{pH}<4)$ fluid with a

425 high sulfate content and high $[\mathrm{Na}] /[\mathrm{K}]$ ratio (Hemley et al., 1969; Stoffregen and Cygan, 1990).

426 Natroalunite precipitation requires fluids with $[\mathrm{Na}] /[\mathrm{K}]$ about 100 (at $\mathrm{pH}=3$; Deyell and

427 Dipple, 2005), much higher than measured in circulating fluids and in whole rock and 428 groundmass compositions at La Soufrière (Boudon et al., 2008; Metcalfe et al., 2021; Villemant 429 et al., 2005), suggesting that equilibrium was not obtained or that the fluids responsible are 
430 different from those discharged at the surface (Deyell and Dipple, 2005). If the fluids are 431 different, acidic $\mathrm{Na}-\mathrm{Cl}-\mathrm{SO}_{4}$ fluids would be required, which form $\mathrm{H}_{2} \mathrm{~S}$ and $\mathrm{H}_{2} \mathrm{SO}_{4}$ following the 432 interaction between $\mathrm{Na}-\mathrm{Cl}$ waters and elemental sulfur at depth (Taran and Kalacheva, 2020). 433 This hypothesis is compatible with the observation that highly acidic chlorine-sulfate rich fluids $434(\mathrm{pH}<1)$ have been rising and circulating within the dome as of early 1998, forming acid ponds 435 within summit craters (Komorowski et al., 2005, Rosas-Carbajal et al., 2016; Villemant et al., 2014). Alternative hypotheses include the interaction of $\mathrm{Na}-\mathrm{Cl}$ neutral water (water/rock volume ratio $>>1$ ) with rocks already showing advanced argillic alteration, and that the rocks collected represent old and buried solfataric fields (Marini et al., 2003) resulting from previous volcanic cycles.

We conclude that the observed secondary mineral assemblages (Table 1) are the result of intense fluid-rock interactions. Advanced argillic alteration of the shallow portion of the edifice was promoted by the efficient circulation of cooled (below $350^{\circ} \mathrm{C}$, and down to $150^{\circ} \mathrm{C}-$ $\left.200^{\circ} \mathrm{C}\right)$, acidic $(\mathrm{pH}<4)$ hydrothermal fluids, possibly mixed with meteoric waters. The alteration assemblages observed at La Soufrière are similar to those commonly identified at domes and craters of active volcanoes worldwide (Heap et al., 2019; Zimbelman et al., 2005; 446 Yilmaz et al., 2021), although the rocks from Mt Unzen volcano (Japan) were overprinted by 447 propylitic alteration (Yilmaz et al., 2021), not observed here. Multiple reaction paths and variable alteration intensity reflect a variable degree of reaction progress. For a given alteration rate, reaction progress will increase as exposure to altering fluids and pathway length increase, 450 or as water flow and water/rock volume ratio decrease. Variations in these environmental 451 parameters simply reflect the heterogeneity and structural complexity of the dome and thus the complex architecture of the hydrothermal system, as revealed by geological and geophysical

453 data (Brothelande et al., 2014; Jessop et al., 2021; Moretti et al., 2020; Nicollin et al., 2006; 454 Rosas-Carbajal et al., 2016; Tamburello et al., 2019). In particular, the complex 3D geometry 
of large faults and fractures in the dome allow for the efficient drainage of fluids and the compartmentalization of supergene and hypogene alteration. In such an environment: (1) intermediate to advanced argillic alteration will develop preferentially along discontinuities favoring fluid circulation, leading to the formation of low-strength layers dominated by clay and sulfate minerals; (2) partial edifice collapse or erosion favored in these weakened zones

460 will expose pyrite-rich zones of the hydrothermal system below the water table and promote 461 the deepening of supergene oxidation and the alteration aureole (as seen in the rain-triggered 462 landslide in 2009; Rosas-Carbajal et al., 2016); and (3) $\mathrm{H}_{2} \mathrm{~S}$ will be easily released by deeper, 463 boiling fluids or by the disproportionation of magmatic $\mathrm{SO}_{2}$ to $\mathrm{H}_{2} \mathrm{~S}$ and aqueous sulfate during 464 the condensation of magmatic vapor plume at intermediate depths.

5.2 The influence of porosity and alteration on uniaxial compressive strength modulus of variably-altered andesites from La Soufrière both decrease as a function of increasing porosity (Figure 3), in accordance with previous studies on volcanic rocks (Heap et al., 2014a, 2020a; Heap and Violay, 2021; Mordensky et al., 2018; Schaefer et al., 2015; Zhu et al., 2016). We compare our new data with those previously published for andesites in Figure $5 \mathrm{a}$ and $5 \mathrm{~b}$, which show that the data for the rocks from La Soufrière are in broad agreement with those previously published. This comparison shows that the andesites forming La 474 Soufrière are generally more porous, and therefore weaker (Figure 5a) and softer (Figure 5b), 475 than andesites from other stratovolcanoes (the block with the lowest porosity, H22, has a 476 porosity of 0.12 ). Indeed, muon tomography data have shown that the material forming the 477 dome at La Soufrière is typically low-density (typically $\leq 1500 \mathrm{~kg} . \mathrm{m}^{-3}$; Lesparre et al., 2012; 478 Rosas-Carbajal et al., 2017) and, therefore, likely comprises high-porosity rocks. However, we 479 note that the relative abundance of high-porosity rocks with a low strength and a low Young's 
modulus from La Soufrière may be a consequence of sampling only 17 blocks. In other words,

481 low-porosity rocks may exist at La Soufrière and, if many more blocks were sampled, maybe

482 the data would encompass a similar range to the compiled dataset for other volcanoes.

483
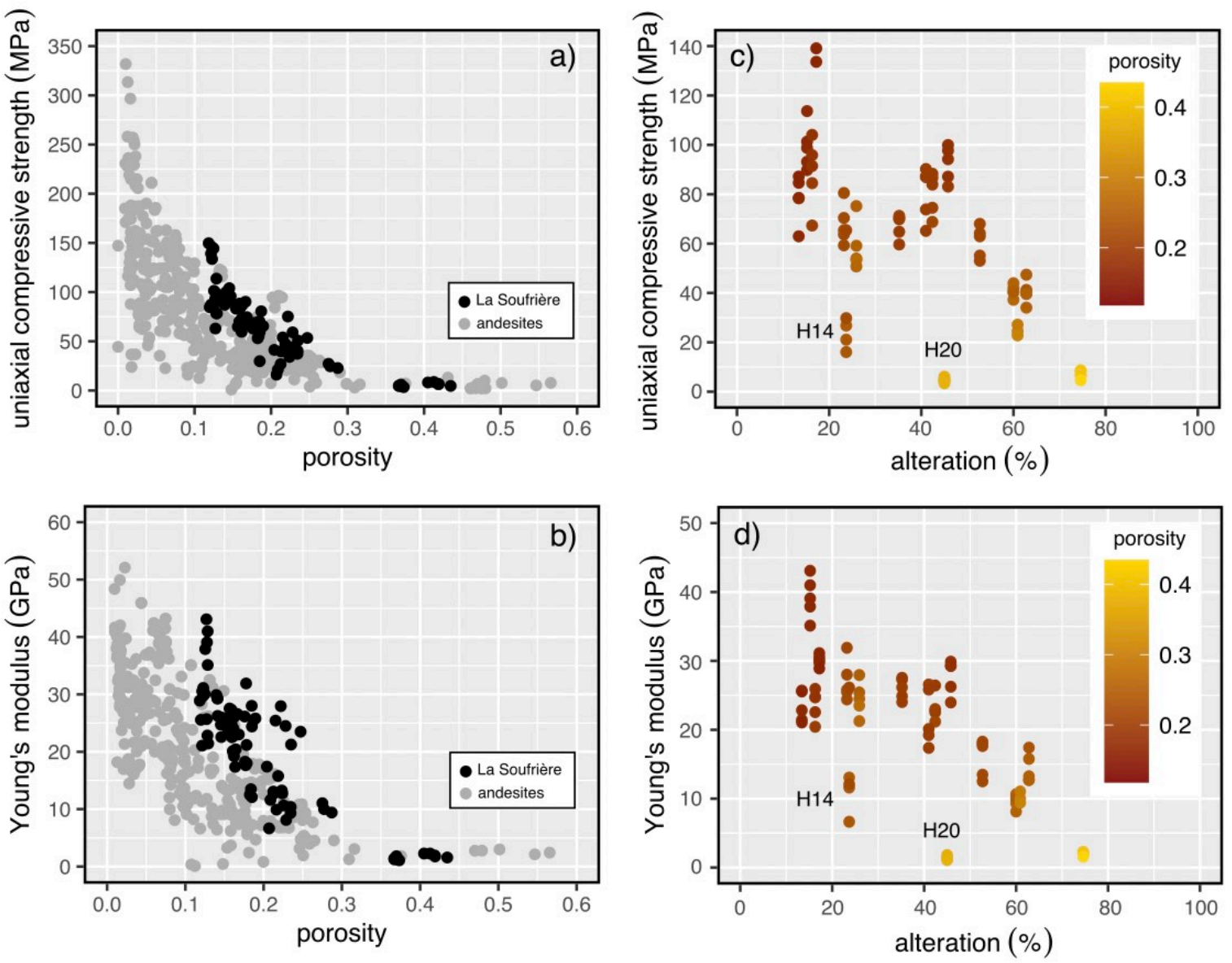

484

Figure 5. (a) Uniaxial compressive strength and (b) Young's modulus as a function of

porosity for andesites from La Soufrière de Guadeloupe (Eastern Caribbean, France) and from

volcanoes worldwide (data from: Karaman and Kesimal, 2015; Heap et al., 2014b; Siratovich et al., 2014; Wyering et al., 2014; Heap et al., 2015a; Mordensky et al., 2018; Harnett et al., 2019; Kennedy et al., 2020; Heap and Violay, 2021). Uniaxial compressive strength (c) and Young's modulus (d) as a function of alteration (the percentage of secondary minerals).

491 Symbol color indicates the connected porosity (red colors indicate low porosity and yellow 
colors indicate high porosity). Outliers - blocks H14 and H20 - are labelled on panels (c) and (d).

$$
\text { Of interest to the goal of this study is whether hydrothermal alteration has influenced }
$$
the compressive strength and Young's modulus of the materials collected. Our triaxial data highlight that alteration (percent of secondary minerals) reduces rock cohesion, but does not systematically influence the angle of internal friction (Figure 4). Experimental studies have shown that alteration can influence the strength of volcanic rock (del Potro and Hürlimann, 2009; Farquharson et al., 2019; Frolova et al., 2014; Heap et al., 2020b, 2021b, Mordensky et al., 2018, 2019; Wyering et al., 2014). The type of alteration, porosity increasing dissolution and alteration to clay (del Potro and Hürlimann, 2009; Farquharson et al., 2019; Opfergelt et al., 2006; Watters and Delahaut, 1995) or porosity decreasing mineral precipitation (Heap et al., 2020b, 2021), dictates whether the alteration decreases or increases the strength and Young's modulus of the rock. Figure 5c and 5d show plots of uniaxial compressive strength and Young's modulus, respectively, as a function of the percentage of secondary minerals for the rocks from La Soufrière. The symbols in Figure $5 \mathrm{c}$ and $5 \mathrm{~d}$ are color-coded to show their porosity: red colors indicate low porosity and yellow colors indicate high porosity. Although there are two notable outliers, Figure $5 \mathrm{c}$ and $5 \mathrm{~d}$, respectively, show that uniaxial compressive strength and Young's modulus decrease as a function of increasing hydrothermal alteration. Uniaxial compressive strength and Young's modulus are reduced from $\sim 60-140$ to $<10 \mathrm{MPa}$ and from $20-45$ to $<5 \mathrm{GPa}$ as alteration increases from $\sim 16-18$ to $\sim 75 \%$ (Figure $5 \mathrm{c}$ and $5 \mathrm{~d}$ ). The low uniaxial compressive strengths and Young's moduli of the two relatively unaltered blocks that form the most obvious outliers (H14 and H20) can be explained by meso-scale fractures found within sample H14 (sample photographs are provided in the Supplementary Information) and the high porosity of sample H20, respectively. Although the data in Figure 5c 
and 5d suggest that an increase in alteration results in a decrease in strength and Young's

518 modulus, it is difficult to untangle the influence of porosity. In other words, are the weak 519 samples weak because of alteration or are the more porous samples simply more altered because

520 of their higher surface area available for rock-fluid interactions? Indeed, our data do show that,

521 in general, alteration increases as a function of increasing porosity. Although laboratory522 controlled hydrothermal alteration experiments (Farquharson et al., 2019) are required to 523 definitively answer this question, we contend here that the observed alteration served to reduce 524 the strength and Young's modulus of these andesites from La Soufrière, regardless of their porosity, due to the presence of abundant clay minerals, phases considered to reduce the strength of volcanic rocks (del Potro and Hürlimann, 2009; Nicolas et al., 2020; Opfergelt et al., 2006; Watters and Delahaut, 1995).

5.3 Influence of alteration on the stability of La Soufrière de Guadeloupe: large-scale numerical modeling

We used the open-source hydro-thermo-mechanical modeling code LaMEM

532 (Lithosphere and Mantle Evolution Model; https://bitbucket.org/bkaus/lamem/src/master/;

533 Kaus et al., 2016), which models the non-linear, visco-elastoplastic deformation of rocks, to 534 investigate the influence of upscaling and alteration on the stability of La Soufrière. This model 535 has recently been used to model large-scale volcano deformation (Heap et al., 2021a). 536 Mathematically, the model solves a coupled system of conservation equations, the conservation 537 equations of momentum and mass. The various deformation mechanisms are connected in an 538 additive constitutive relationship, where the total strain rate is the sum of the individual strain 539 rates of elastic, viscous, and plastic deformation. LaMEM uses the Drucker-Prager failure 540 criterion to determine the magnitude of the plastic strain rate. Numerically, LaMEM uses a 541 staggered-grid finite difference method for discretization and a marker-and-cell method to 
assign and track rock properties within a Eulerian advection framework (Harlow and Welch,

543 1965). This approach enables the model to attain the large deformations required in, for

544 example, salt tectonics, continental collision, and magmatic systems (Baumann et al., 2014;

545 Pusok and Kaus, 2015; Reuber et al., 2018). The ability to model large deformations is seen

546 here as an advantage of LaMEM over commonly-used commercial packages such as FLAC (by

547 Itasca Consulting Group), RS2 (by Rocscience), and PLAXIS 2D (by Virtuosity). We refer the

548 reader to Kaus et al. (2016) and the Supplementary Information for a more detailed description

549 of LaMEM.

550 Models were run on simplified 2D North-South cross-sections of the volcano (643 km

551 Easting), built using the geomIO tool (Bauville and Baumann, 2019). The model domain was

552 first separated into deformable and non-deformable domains, guided by geological

553 observations and the recent electrical survey of Rosas-Carbajal et al. (2016). The models have

554 a dimension of $2000 \times 800 \mathrm{~m}$, a model resolution of $4 \times 3 \mathrm{~m}$, free-slip boundary conditions at

555 the sides, and a free surface at the top. All our models assumed an entirely liquid saturated

556 volcano. The average topographic height was used as the reference surface for determining the

557 hydrostatic pressure, $p_{h}$, using $p_{f}=p_{h}+\lambda_{i}\left(p_{\text {lith }}-p_{h}\right)$, where $p_{f}$ and $p_{\text {lith }}$ are the pore

558 fluid and lithostatic pressure, respectively, and $\lambda_{i}$ is the pore fluid pressure ratio. Following

559 Heap et al. (2021a), we assumed a value of 0.2 for $\lambda_{i}$ (Table 4). To account for the uncertainty

560 in $\lambda_{i}$, additional models using $\lambda_{i}=0.4$ are provided in the Supplementary Information. We

561 highlight that, although the assumption of complete volcano saturation is an oversimplification

562 (Ball et al., 2015, 2018; Hurwitz et al., 2003), the main goal of our modeling was to understand,

563 all else being equal, whether hydrothermal alteration is a contributing factor to the deformation

564 observed at La Soufrière. Further, the distribution of liquid-saturated and dry zones within the

565 volcano is currently poorly constrained. However, using the average topographic height as the 
reference surface resulted in a "dry" volcano summit with a pore fluid pressure of zero (see

567 Supplementary Information for further details).

By modifying the segmentation of the deformable domain, we prepared three cross-

sections: (1) a homogeneous volcano, (2) a volcano containing alteration zones identified by

the electrical conductivity data of Rosas-Carbajal et al. (2016), and (3) a volcano in which we

571 artificially enlarged the highly altered zone identified by Rosas-Carbajal et al. (2016). Zones

572 within the volcano cross-sections were designated as either slightly altered (V3), moderately

573 altered (V2), or highly altered (V1) (Figures 6a-d). Zones V3, V2, and V1 were assigned the

574 mechanical properties of samples H18, H6, and H2B, respectively, the three blocks chosen to

575 represent relatively unaltered, moderately altered, and highly altered rock (Figure 2; Table 1).

576 The laboratory data used in the modeling were: water-saturated bulk density, Young' modulus,

577 cohesion, and the angle of internal friction. Poisson's ratio, not measured here, was assumed to

578 be 0.2 (as recommended by Heap et al., 2020a). The model parameters for V3, V2, and V1 are

579 provided in Table 4. As the models are dynamic, we must decide when the models reach a

580 quasi-steady state and can be compared (see Baumann and Kaus, 2015). Here, we stop the

581 models after an initial deformation phase that is dominated by an elastic response. For each of

582 the three modeled scenarios, we ran one model in which we used the laboratory data and one

583 model in which we used upscaled values of the laboratory data (Table 4).

\begin{tabular}{|c|c|c|c|}
\hline & V1 (highly altered) & V2 (moderately altered) & $\begin{array}{c}\text { V3 (relatively } \\
\text { unaltered) }\end{array}$ \\
\hline & \multicolumn{3}{|c|}{ Laboratory-scale input parameters } \\
\hline Bulk density $\left(\mathrm{kg} / \mathrm{m}^{3}\right)$ & 1900 & 2400 & 2500 \\
\hline Young's modulus $(\mathrm{GPa})$ & 0.4 & 9.6 & 0.3 \\
\hline Poisson's ratio & 0.2 & 0.2 & 14.8 \\
\hline Cohesion $(\mathrm{MPa})$ & 0.4 & 7.1 & 46.7 \\
\hline Internal friction angle $\left(^{\circ}\right)$ & 42.5 & 37.7 & 0.2 \\
\hline Pore fluid pressure ratio & 0.2 & 0.2 & 2500 \\
\hline \multicolumn{2}{|c|}{ Upscaled input parameters } \\
\hline Bulk density $\left(\mathrm{kg} / \mathrm{m}^{3}\right)$ & 1900 & 2400 & 8.3 \\
\hline Young's modulus $(\mathrm{GPa})$ & 0.2 & 3.9 & 0.3 \\
\hline Poisson's ratio & 0.3 & 0.3 & \\
\hline
\end{tabular}


585

586

587

588

589

590

591

592

593

594

595

596

597

598

599

600

601

602

603

604

605

606

\begin{tabular}{|c|c|c|c|}
\hline Cohesion $(\mathrm{MPa})$ & 0.67 & 1.09 & 2.02 \\
\hline Internal friction angle $\left(^{\circ}\right)$ & 30.1 & 33.5 & 46.4 \\
\hline Pore fluid pressure ratio & 0.2 & 0.2 & 0.2 \\
\hline
\end{tabular}

Table 4. Laboratory-scale and upscaled input parameters for the numerical modeling performed using hydro-thermo-mechanical modeling code LaMEM (Lithosphere and Mantle Evolution Model).

The laboratory-scale Young's modulus and Poisson's ratio were upscaled using empirical relationships for Young's modulus (Hoek and Diederichs, 2006) and Poisson's ratio (Vásárhelyi, 2009) that account for rock-mass structure using the Geological Strength Index (GSI), as described in Heap et al. (2020a). Following Heap et al. (2020a), GSI was assumed to be 55 and the damage parameter in the Hoek-Diederichs equation was considered zero. The cohesion and angle of internal friction were upscaled by transforming the generalized form of the Hoek-Brown failure criterion to the Mohr-Coulomb failure criterion (as in Hoek et al., 2002). We used the mean uniaxial compressive strength of samples H18, H6, and H2B for layers V3, V2, and V1, respectively. The empirical fitting parameter $m_{i}$ required for the generalized Hoek-Brown failure criterion was determined from the triaxial data (Figure 4) using RocData (Rocscience; https://www.rocscience.com). To do so, we again assumed a GSI of 55 and a damage parameter of zero. Since a depth is required to upscale the cohesion and angle of internal friction, we selected a depth half of that between the summit of the volcano and the top of the undeformable zone in the model $(275 \mathrm{~m})$. The upscaled model parameters for V3, V2, and V1 are provided in Table 4. A more detailed description of the upscaling methods can be found in the Supplementary Information. 


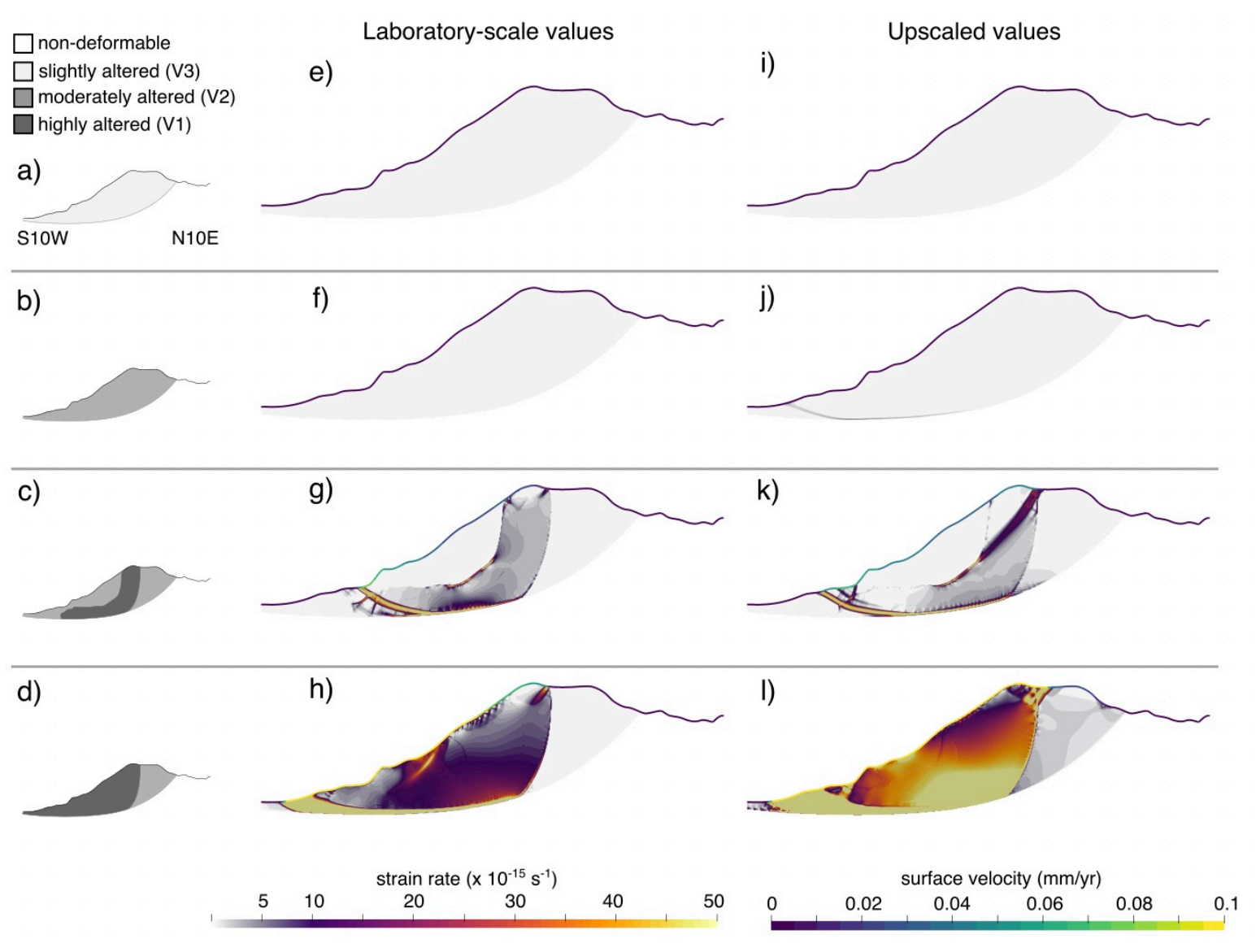

607

608 Figure 6. Results of the large-scale 2D numerical modeling designed to better understand the

609 influence of alteration on the stability of La Soufrière de Guadeloupe Eastern (Caribbean,

610 France). Panels (a-d) show the model setup, in which white, light grey, grey, and dark grey

611 indicate non-deformable, slightly altered (V3), moderately altered (V2), and highly altered

612 (V1) zones. Panels (e-h) and (i-1) show the model results for the models run using laboratory-

613 scale and upscaled mechanical properties, respectively. The color of the line representing the

614 surface of the volcano indicates the surface velocity $(\mathrm{mm} / \mathrm{yr})$ and the color inside the volcano

615 indicates the strain rate $\left(\mathrm{s}^{-1}\right)$.

616

617 The model results, the velocity magnitude at the surface and the $2^{\text {nd }}$ invariant of the 618 deviatoric strain rate tensor, which we refer to as the strain rate, within the deformable domain, 619 are presented in Figure 6. The strain rate allows us to understand whether the deformation is 
widespread or localized, and the velocity at the surface can be compared to geophysical data. Figures 6e-h and 6i-1 show model runs using the laboratory-scale and upscaled values, respectively. We first highlight that our results emphasize the importance of using upscaled values for large-scale modeling. Not only are the strain rates and velocities much lower when using the laboratory-scale values, but the deformation also manifests slightly differently (Figure $6)$.

To discuss the influence of alteration, we will restrict our discussion to the upscaled models (Figures 6i-1). We first note that strain rates and velocities are low in the homogenously altered volcanoes, that deformation is largely restricted to the surface and the base of southern slope, and that there is little difference in strain rates and velocities when the alteration is increased from slightly to moderately altered (Figures $6 \mathrm{i}$ and $6 \mathrm{j}$ ). When the highly-altered zone guided by the recent electrical survey of Rosas-Carbajal et al. (2016) is included, the strain rates and velocities increase significantly (Figure 6k). Surface velocities increase from $<0.01$ to $\sim 0.05 \mathrm{~mm} / \mathrm{yr}$ and a large listric, concave-upward sliding surface emerges, which stretches from the top of the dome to near the base of the southern flank (Figure 6k). A localized slip surface at the base of the deformable domain and two smaller slip surfaces also emerge near the base of the southern flank (Figure 6k). Therefore, the inclusion of the highly altered zone, the consequence of pervasive alteration resulting from the circulation of acid hydrothermal fluids (Rosas-Carbajal et al., 2016), has significantly increased volcano deformation rates and therefore decreased the stability of the volcano. As outlined above, recent manifestations of increased hydrothermal activity, such as fumaroles and hot springs (Moretti et al., 2020; Jessop et al., 2021), also provide evidence that the measured ground deformation is, in part, due to the alteration of the rock forming the dome. Continuous and campaign Global Navigation Satellite System (GNSS) measurements over $\sim 20$ years show that the dome is sliding at a rate of $0.3-$ $0.7 \mathrm{~cm} / \mathrm{yr}$ (Moretti et al., 2020). Therefore, although our modeling captures the dynamics of the 
645 deformation of the southern flank, our simplified 2D model setup (Figure 6) underestimates the

646 deformation measured at the volcano. This underestimation is likely the result of the presence

647 of large-scale faults, discontinuities, extremely weak clay-rich layers, and zones of high pore

648 pressure, not included in our modeling. Indeed, the strain rate in the southern flank increases

649 when we increase the pore fluid pressure ratio, $\lambda_{i}$, from 0.2 to 0.4 (see additional models

650 presented in the Supplementary Information). Future models will aim to incorporate these 651 features.

In a final step, and to further explore how alteration can influence volcano stability, we modeled a scenario in which the highly altered zone identified by Rosas-Carbajal et al. (2016)

654 was artificially enlarged to incorporate the entire southern flank (Figure 6d). Increasing the size 655 of the alteration zone increases the surface velocities from $\sim 0.05$ to $\sim 0.1 \mathrm{~mm} / \mathrm{yr}$ and 656 significantly increases the strain rate within the flank (Figure 61). The slip surface that at the 657 base of the deformable domain is now larger and has a higher strain rate, and the entire southern 658 flank is now characterized by higher strain rates (Figure 61). In addition, we also observe that 659 expanding the alteration zone likely increases the potential collapse volume (Figure 61). Based 660 on these models, increasing the size of the highly altered zone (i.e. to a size larger than the 661 present-day altered zone) will significantly increase the risk posed by the volcano. Deformation snapshots from additional models, presented in the Supplementary Information, show the

663 progression of deformation for the present-day and increased-alteration scenarios from 5 to 100 664 kyrs (using upscaled physical and mechanical properties). These additional models also show 665 that increasing the extent of the alteration increases the rate of volcano spreading.

666

6675.4 Three-dimensional strength model for La Soufrière de Guadeloupe

668 The results of the previous section highlight the importance of combining geophysical 669 surveys, laboratory data, and large-scale modeling to evaluate the influence of alteration on 
670 volcanic flank instability. Our 2D model geometry is based on qualitative interpretations from 671 an electrical conductivity model to delimit different regions based on their degree of alteration.

672 A quantitative approach would require a petrophysical relation to convert the conductivity 673 values to rock strength and cohesion, but such relations are highly non-unique as electrical 674 conductivity depends on many factors including clay content, fluid temperature, and 675 composition. Instead, rock strength is controlled to a first order by porosity, as shown in Figure $6763 \mathrm{~b}$, and thus to the bulk rock density.

677 Here, we combine a 3D model of the bulk density of the present-day lava dome (Rosas678 Carbajal et al., 2017) with an empirical power-law function relating wet bulk density and 679 uniaxial compressive strength, $\sigma_{p}$, where $\sigma_{p}=1.326^{-25} \rho_{w}{ }^{9.67}\left(\sigma_{p}\right.$ in Pa and $\rho_{w}$ in $\left.\mathrm{kg} / \mathrm{m}^{3}\right)$ to 680 create a 3D strength map of the volcano (Figure 7). The empirical function was specifically 681 fitted to our new data for La Soufrière (Table 2; Figure 7a). Because the distribution of liquid682 saturated and dry zones within the volcano is currently poorly constrained, we chose to use the 683 bulk density of our samples saturated with liquid water, a scenario we consider better represents 684 the natural state of the volcano than a completely dry volcano. The 3D bulk density model of 685 Rosas-Carbajal et al. (2017) was obtained by jointly inverting gravity data and muon data 686 acquired using three simultaneous muon detectors that scanned the lava dome from different 687 points of view. Muon tomography is a novel technique, which uses the attenuation experienced 688 by cosmic muons as they pass through the volcano to estimate its density (Tanaka et al., 2010). 689 Whereas a single detector can provide 2D profiles of the average density of the volcano in the 690 different directions sampled, multiple simultaneous detectors from different points of view can 691 be used to create a 3D model of the volcano (Bonechi et al., 2020). 

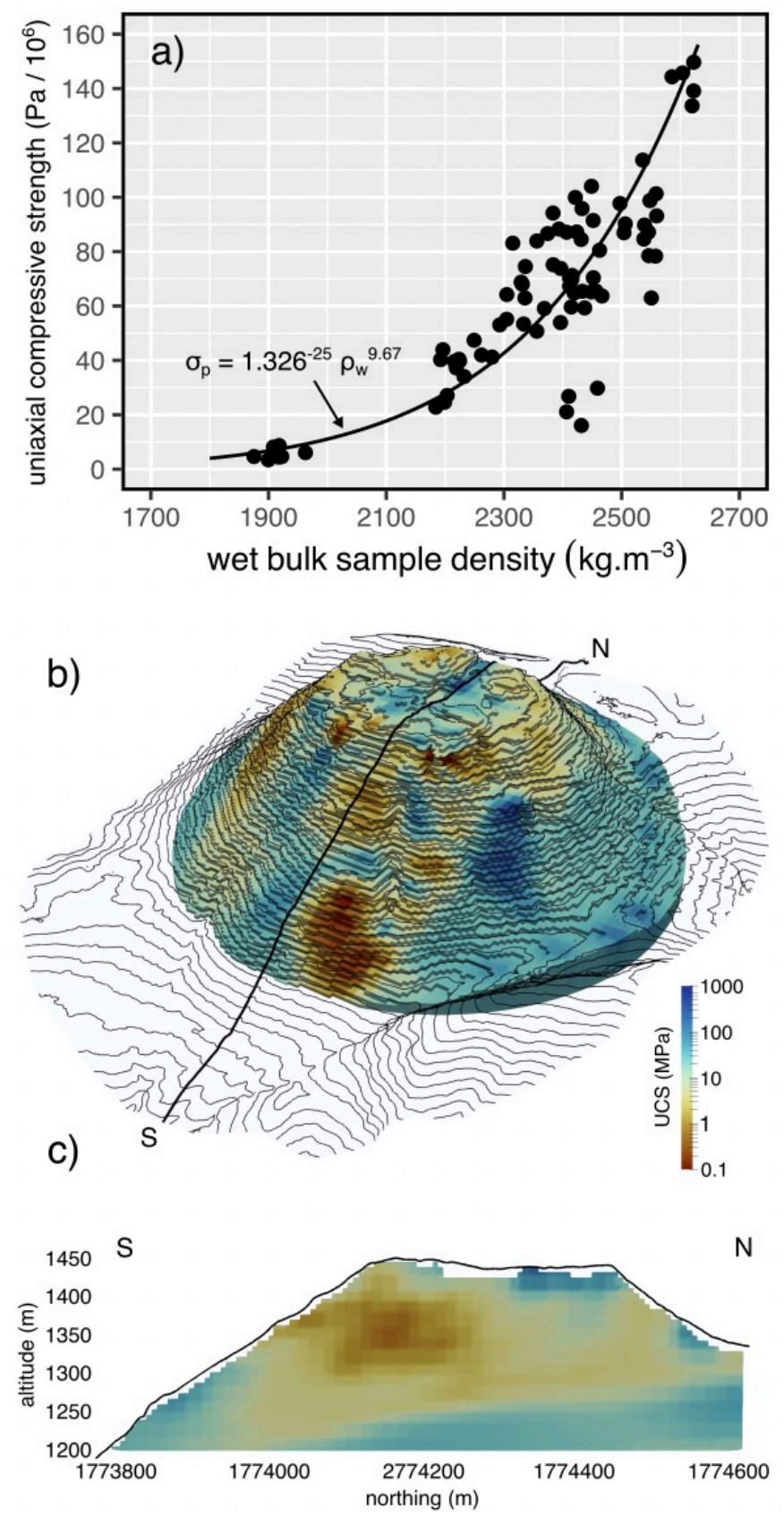

692

$693 \quad$ Figure 7. (a) Uniaxial compressive strength as a function of wet bulk sample density for

694 andesites from La Soufrière de Guadeloupe (Eastern Caribbean, France). Curve is the best-fit

695 empirical power-law function. (b) 3D uniaxial compressive strength map of La Soufrière de 696 Guadeloupe (Eastern Caribbean, France). The black line, which runs North-South, indicates 697 the position of the cross-section in panel (c). (c) North-South cross-section through La 698 Soufrière showing the distribution of uniaxial compressive strength. Color scale is the Roma 
(seismic tomography) color scale of Fabio Crameri (Crameri et al., 2020). UCS - uniaxial compressive strength.

Figure 7 highlights that large portions of the dome are characterized by very low values of strength $(<5 \mathrm{MPa})$. In particular, the southern flank of the volcano hosts a significant weak zone (Figures $7 \mathrm{~b}$ and $7 \mathrm{c}$ ). This low-strength zone is coincident with the location of the main hydrothermal reservoir at La Soufrière, as exposed by electrical conductivity measurements (Lesparre et al., 2012; Rosas-Carbajal et al., 2016). Based on (1) the influence of hydrothermally altered rock on edifice stability and spreading rates at La Soufrière revealed by the numerical modeling in the previous section, and (2) the large volume of low-strength rock in the La Soufrière dome highlighted by our 3D strength model, we conclude that the stability of La Soufrière is compromised by its high degree of rock alteration, and that the rate of volcano spreading and the probability of an eventual partial edifice collapse may increase solely due to the ongoing alteration caused by circulating hydrothermal fluids, and may not necessarily require intensified hydrothermal and/or magmatic activity.

Based on our 3D strength model, we can provide estimates for the volumes of rock within the lava dome below a certain strength threshold. For example, we estimate that rock with a strength lower than 1 and $10 \mathrm{MPa}$ comprises minimum dome volumes of $2.7 \times 10^{6}$ and $36 \times 10^{6} \mathrm{~m}^{3}$, respectively, corresponding to at least $4 \%$ and $55 \%$ of the dome above $1200 \mathrm{~m}$. In other words, more than half of the La Soufrière dome could be considered to have a low strength. We highlight that these volume and percentage estimates should be considered conservative due to the positioning of the three telescopes at La Soufrière, which provides better coverage of the southern flank of the volcano (Rosas-Carbajal et al., 2017). It is likely, therefore, that the volumes and percentages of weak rock within the dome at La Soufrière are higher than estimated here. 
Although the strength map shown in Figure 7 is currently simplistic (for example, it is well known that strength increases with depth in the brittle field; Heap et al., 2015b; Figure 4), this 3D model permits the quick identification of zones within the volcano that could promote instability and more experimental data, when available, will allow us to account for depth and other factors that can influence rock mechanical behavior, such as temperature and saturation state (Heap and Violay, 2021).

\section{Conclusions}

Hydrothermal alteration is often invoked as a mechanism that greatly contributes to volcano instability (Reid et al., 2001; van Wyk de Vries et al., 2000). However, owing to the paucity of experimental data and the difficulty in accurately imaging subsurface alteration zones, the rock properties and the shape and size of the alteration zones required for large-scale modeling are often poorly constrained or even assumed. Here we use a combination of laboratory and geophysical data to numerically model the influence of hydrothermal alteration on volcano stability, using La Soufrière de Guadeloupe as a case study. Our numerical modeling suggests that hydrothermal alteration can significantly increase the deformation rate within the flanks of the volcano, and also increase the potential collapse volume.

The volcano stability modeling and 3D strength map presented herein, firsts for La Soufriere, help to validate the hypothesis forwarded by the numerous geophysical studies performed at the volcano: that the identified hydrothermal reservoir characterized by altered materials promotes volcano instability that could result in collapse (Bouligand et al., 2016; Brothelande et al., 2014; Lesparre et al., 2012; Nicollin et al., 2006; Rosas-Carbajal et al., 2016, 2017). As discussed above, eventual partial edifice collapse at La Soufrière may not necessarily require intensified hydrothermal and/or magmatic activity. Not only would the debris avalanche resulting from partial or major dome collapse threaten the inhabited areas surrounding the 
volcano (Le Friant, 2006; Peruzzetto et al., 2019), but collapse could also depressurize the

750 hydrothermal system leading to steam-driven eruptions, dangerous laterally-directed 751 explosions, and associated high energy pyroclastic density currents, similar to the activity 752 during the 1976-1977 volcanic crisis (Feuillard et al., 1983; Komorowski et al., 2005). We also 753 highlight that the fragmentation threshold (the overpressure required for complete 754 fragmentation upon depressurization), the proportion of fines produced as a result of 755 fragmentation, and the ejection speed are also influenced by hydrothermal alteration (Mayer et 756 757 758

al., 2015, 2016; 2017; Montanaro et al., 2016), reinforcing the need for a multidisciplinary approach to unravel how hydrothermal alteration affects volcanic hazards (see also de Moor et al., 2019; Mick et al., 2021).

Our modeling and 3D strength map therefore highlight the importance of monitoring the extent and evolution of hydrothermal alteration, and the formation of low-strength altered layers, at La Soufrière and at other active volcanoes worldwide. Such monitoring can be achieved, for example, using geophysical methods such as electrical tomography (Ahmed et al., 2018; Byrdina et al., 2017; Ghorbani et al., 2018; Rosas-Carbajal et al., 2016) and muon tomography (Lesparre et al., 2012; Rosas-Carbajal et al., 2017), near-surface seismic imaging (Amoroso et al., 2018), thermal and gas monitoring (de Moor et al., 2019; Edmonds et al., 2003; Jessop et al., 2021; Moretti et al., 2020; Tamburello et al., 2019), geological mapping (van Wyk de Vries et al., 2000), deformation monitoring (Moretti et al., 2020), magnetic methods (Finn et al., 2007), and remote and/or ground-based optical and spectroscopic methods (Crowley and Zimbelman, 1997; Darmawan et al., 2018; John et al., 2008; Kereszturi et al., 2020; Mueller et al., 2021). Further, although we document a reduction in strength as a function of alteration (Figure 5c), alteration can also increase strength and potentially promote volcanic instability by creating zones of high pore fluid pressure (Heap et al., 2021a; Reid, 2004). As noted in Heap et al. (2021a), it is important not only to map the extent and evolution of hydrothermal 
774 alteration, but also the locations in the volcano prone to porosity increasing and porosity 775 decreasing alteration.

We have also shown that microtextural and mineralogical analysis of host-rock material

777 erupted during phreatic explosive eruptions, as well as material from landslides and debrisavalanche deposits, can provide highly valuable insights into the nature, extent, and dynamics of alteration processes and fluid circulation in the pre-collapse edifice (see also Boudon et al., 1998; Komorowski et al., 2010; Salaün et al., 2011). Hence, we highlight that it is also important to quantify the mineral content of new material exposed by landslides and collapses, as well as their deposits, and to continuously monitor fluid compositions and water table fluctuations (Hurwitz et al., 2003) with respect to the geometry of weakened low-strength structures that are characteristic of the internal framework volcanic edifices hosting hydrothermal systems. A better understanding of the spatio-temporal evolution of hydrothermal alteration, and how it can influence volcano stability using large-scale modeling, will help improve the mitigation of volcanic hazards at active volcanoes worldwide.

\section{Acknowledgements}

This work was supported by the TelluS Program of INSU-CNRS ("Assessing the role of hydrothermal alteration on volcanic hazards") and ANR grant MYGALE ("Modelling the phYsical and chemical Gradients of hydrothermal ALteration for warning systems of flank collapse at Explosive volcanoes"), awarded to the first author. M. Heap also acknowledges support from the Institut Universitaire de France (IUF). We thank Tomaso Esposti Ongaro, Gilles Morvan, Christophe Nevado, Marie Cherrier, Océane Rocher, and Lisa Tomasetto. We thank the IPGP for general funding for the Observatoires Volcanologiques et Sismologiques (OVS), INSU-CNRS for the funding provided by the Service National d'Observation en Volcanologie (SNOV), and the Ministère pour la Transition Ecologique (MTE) for financial 
All the mechanical data collected for this study can be downloaded here:

\section{References}

806

807

808

809

810

811

812

813

814

815

816

817

818

819

820

821

822

823

824

825

826

827

828

829

830

831

832

833

834

835

836

837

838

839

840

841

842

843

844

845

846

847

848

Ahmed, A. S., Revil, A., Byrdina, S., Coperey, A., Gailler, L., Grobbe, N., ... \& Hogg, C. (2018). 3D electrical conductivity tomography of volcanoes. Journal of Volcanology and Geothermal Research, 356, 243-263.

Amoroso, O., Festa, G., Bruno, P. P., D'Auria, L., De Landro, G., Di Fiore, V., ... \& Zollo, A. (2018). Integrated tomographic methods for seismic imaging and monitoring of volcanic caldera structures and geothermal areas. Journal of Applied Geophysics, 156, 16-30.

Ball, J. L., Calder, E. S., Hubbard, B. E., \& Bernstein, M. L. (2013). An assessment of hydrothermal alteration in the Santiaguito lava dome complex, Guatemala: implications for dome collapse hazards. Bulletin of Volcanology, 75(1), 1-18.

Ball, J. L., Stauffer, P. H., Calder, E. S., \& Valentine, G. A. (2015). The hydrothermal alteration of cooling lava domes. Bulletin of Volcanology, 77(12), 1-16.

Ball, J. L., Taron, J., Reid, M. E., Hurwitz, S., Finn, C., \& Bedrosian, P. (2018). Combining multiphase groundwater flow and slope stability models to assess stratovolcano flank collapse in the Cascade Range. Journal of Geophysical Research: Solid Earth, 123(4), 2787-2805.

Baumann, T. S., Kaus, B. J., \& Popov, A. A. (2014). Constraining effective rheology through parallel joint geodynamic inversion. Tectonophysics, 631, 197-211.

Baumann, T. S., \& Kaus, B. J. (2015). Geodynamic inversion to constrain the non-linear rheology of the lithosphere. Geophysical Journal International, 202(2), 1289-1316.

Bauville, A., \& Baumann, T. S. (2019). geomIO: An Open-Source MATLAB Toolbox to Create the Initial Configuration of 2-D/3-D Thermo-Mechanical Simulations From 2-D Vector Drawings. Geochemistry, Geophysics, Geosystems, 20(3), 1665-1675.

Bonechi, L., D’Alessandro, R., \& Giammanco, A. (2020). Atmospheric muons as an imaging tool. Reviews in Physics, 5, 100038.

Borgia, A., Delaney, P. T., \& Denlinger, R. P. (2000). Spreading volcanoes. Annual Review of Earth and Planetary Sciences, 28(1), 539-570.

Boudon, G., Semet, M. P., \& Vincent, P. M. (1987). Magma and hydrothermally driven sector collapses: The 3100 and 11,500 y. BP eruptions of la Grande Decouverte (la Soufriere) volcano, Guadeloupe, French West Indies. Journal of Volcanology and Geothermal Research, 33(4), 317-323.

Boudon, G., Villemant, B., Komorowski J.-C., Ildefonse, P., Semet, M.P. (1998) The hydrothermal system at Soufriere Hills volcano, Montserrat (West Indies): Characterization and role in the ongoing eruption. Geophysical Research Letters, 25: 3693-3696

Boudon, G., Komorowski, J.-C., Villemant, B., \& Semet, M. P. (2008). A new scenario for the last magmatic eruption of La Soufrière of Guadeloupe (Lesser Antilles) in 1530 AD Evidence from stratigraphy radiocarbon dating and magmatic evolution of erupted products. Journal of Volcanology and Geothermal Research, 178(3), 474-490.

Bouligand, C., Coutant, O., \& Glen, J. M. (2016). Sub-surface structure of La Soufrière of Guadeloupe lava dome deduced from a ground-based magnetic survey. Journal of Volcanology and Geothermal Research, 321, 171-181.

Brombach, T., Marini, L., \& Hunziker, J. C. (2000). Geochemistry of the thermal springs and fumaroles of BasseTerre Island, Guadeloupe, Lesser Antilles. Bulletin of Volcanology, 61(7), 477-490.

Brothelande, E., Finizola, A., Peltier, A., Delcher, E., Komorowski, J. C., Di Gangi, F., ... \& Legendre, Y. (2014). Fluid circulation pattern inside La Soufrière volcano (Guadeloupe) inferred from combined electrical resistivity tomography, self-potential, soil temperature and diffuse degassing measurements. Journal of Volcanology and Geothermal Research, 288, 105-122. 
Browne, P. R. L. (1978). Hydrothermal alteration in active geothermal fields. Annual Review of Earth and Planetary Sciences, 6, 229-250.

Byrdina, S., Friedel, S., Vandemeulebrouck, J., Budi-Santoso, A., Suryanto, W., Rizal, M. H., \& Winata, E. (2017). Geophysical image of the hydrothermal system of Merapi volcano. Journal of Volcanology and Geothermal Research, 329, 30-40.

Crameri, F., Shephard, G. E., \& Heron, P. J. (2020). The misuse of colour in science communication. Nature Communications, 11(1), 1-10.

Cecchi, E., van Wyk de Vries, B., \& Lavest, J. M. (2004). Flank spreading and collapse of weak-cored volcanoes. Bulletin of Volcanology, 67(1), 72-91.

Cole, P. D., Neri, A., \& Baxter, P. J. (2015). Hazards from pyroclastic density currents. In The Encyclopedia of Volcanoes (pp. 943-956). Academic Press.

Crowley, J. K., \& Zimbelman, D. R. (1997). Mapping hydrothermally altered rocks on Mount Rainier, Washington, with airborne visible/infrared imaging spectrometer (AVIRIS) data. Geology, 25(6), 559-562.

Damby, D. E., Llewellin, E. W., Horwell, C. J., Williamson, B. J., Najorka, J., Cressey, G., \& Carpenter, M. (2014). The $\alpha-\beta$ phase transition in volcanic cristobalite. Journal of Applied Crystallography, 47(4), 12051215.

Darmawan, H., Walter, T. R., Brotopuspito, K. S., \& Nandaka, I. G. M. A. (2018). Morphological and structural changes at the Merapi lava dome monitored in 2012-15 using unmanned aerial vehicles (UAVs). Journal of Volcanology and Geothermal Research, 349, 256-267.

Day, S. J. (1996). Hydrothermal pore fluid pressure and the stability of porous, permeable volcanoes. Geological Society, London, Special Publications, 110(1), 77-93.

de Moor, J. M., Stix, J., Avard, G., Muller, C., Corrales, E., Diaz, J. A., ... \& Fischer, T. P. (2019). Insights on hydrothermal-magmatic interactions and eruptive processes at Poás Volcano (Costa Rica) from highfrequency gas monitoring and drone measurements. Geophysical Research Letters, 46(3), 1293-1302.

del Potro, R., \& Hürlimann, M. (2009). The decrease in the shear strength of volcanic materials with argillic hydrothermal alteration, insights from the summit region of Teide stratovolcano, Tenerife. Engineering Geology, 104(1-2), 135-143.

Deyell, C. L., \& Dipple, G. M. (2005). Equilibrium mineral-fluid calculations and their application to the solid solution between alunite and natroalunite in the El Indio-Pascua belt of Chile and Argentina. Chemical Geology, 215(1-4), 219-234.

Edmonds, M., Oppenheimer, C., Pyle, D. M., Herd, R. A., \& Thompson, G. (2003). SO2 emissions from Soufrière Hills Volcano and their relationship to conduit permeability, hydrothermal interaction and degassing regime. Journal of Volcanology and Geothermal Research, 124(1-2), 23-43.

Ellis, A. J., \& Mahon, W. A. J. (1977). Chemistry and geothermal systems (No. 553.79 E4).

Farquharson, J. I., Wild, B., Kushnir, A. R., Heap, M. J., Baud, P., \& Kennedy, B. (2019). Acid-induced dissolution of andesite: evolution of permeability and strength. Journal of Geophysical Research: Solid Earth, 124(1), 257-273.

Feuillard, M., Allegre, C. J., Brandeis, G., Gaulon, R., Le Mouel, J. L., Mercier, J. C., ... \& Semet, M. P. (1983). The 1975-1977 crisis of La Soufrière de Guadeloupe (FWI): a still-born magmatic eruption. Journal of Volcanology and Geothermal Research, 16(3-4), 317-334.

Feuillet, N., F. Beauducel, E. Jacques, P. Tapponnier, B. Delouis, S. Bazin, M. Vallée, and G. C. P. King (2011), The Mw $=6.3$, November 21, 2004, Les Saintes earthquake (Guadeloupe): Tectonic setting, slip model and static stress changes, Journal of Geophysical Research, 116, B10301, doi:10.1029/2011JB008310.

Finn, C. A., Deszcz-Pan, M., Ball, J. L., Bloss, B. J., \& Minsley, B. J. (2018). Three-dimensional geophysical mapping of shallow water saturated altered rocks at Mount Baker, Washington: Implications for slope stability. Journal of Volcanology and Geothermal Research, 357, 261-275.

Frolova, J., Ladygin, V., Rychagov, S., \& Zukhubaya, D. (2014). Effects of hydrothermal alterations on physical and mechanical properties of rocks in the Kuril-Kamchatka island arc. Engineering Geology, 183, 80-95.

Ghorbani, A., Revil, A., Coperey, A., Ahmed, A. S., Roque, S., Heap, M. J., ... \& Viveiros, F. (2018). Complex conductivity of volcanic rocks and the geophysical mapping of alteration in volcanoes. Journal of Volcanology and Geothermal Research, 357, 106-127.

Girona, T., Realmuto, V., \& Lundgren, P. (2021). Large-scale thermal unrest of volcanoes for years prior to eruption. Nature Geoscience, 14(4), 238-241.

Glicken, H. (1996). Rockslide-debris avalanche of May 18, 1980, Mount St. Helens volcano, Washington (No. 96677). US Geological Survey.

Harlow, F. H., \& Welch, J. E., 1965. Numerical calculation of time-dependent viscous incompressible flow of fluid with free surface. The Physics of Fluids, 8(12), 2182-2189.

Harnett, C. E., Kendrick, J. E., Lamur, A., Thomas, M. E., Stinton, A., Wallace, P. A., ... \& Lavallée, Y. (2019). Evolution of mechanical properties of lava dome rocks across the 1995-2010 eruption of Soufrière Hills volcano, Montserrat. Frontiers in Earth Science, 7, 7. 
Heap, M. J., Xu, T., \& Chen, C.-f. (2014a). The influence of porosity and vesicle size on the brittle strength of volcanic rocks and magma. Bulletin of Volcanology, 76(9), 856.

Heap, M. J., Lavallée, Y., Petrakova, L., Baud, P., Reuschlé, T., Varley, N. R., \& Dingwell, D. B. (2014b). Microstructural controls on the physical and mechanical properties of edifice-forming andesites at Volcán de Colima, Mexico. Journal of Geophysical Research: Solid Earth, 119(4), 2925-2963.

Heap, M. J., Kennedy, B. M., Pernin, N., Jacquemard, L., Baud, P., Farquharson, J. I., ... \& Dingwell, D. B. (2015a). Mechanical behaviour and failure modes in the Whakaari (White Island volcano) hydrothermal system, New Zealand. Journal of Volcanology and Geothermal Research, 295, 26-42.

Heap, M. J., Farquharson, J. I., Baud, P., Lavallée, Y., \& Reuschlé, T. (2015b). Fracture and compaction of andesite in a volcanic edifice. Bulletin of Volcanology, 77(6), 55.

Heap, M. J., Troll, V. R., Kushnir, A. R., Gilg, H. A., Collinson, A. S., Deegan, F. M., ... \& Walter, T. R. (2019). Hydrothermal alteration of andesitic lava domes can lead to explosive volcanic behaviour. Nature Communications, 10(1), 1-10.

Heap, M. J., Villeneuve, M., Albino, F., Farquharson, J. I., Brothelande, E., Amelung, F., ... \& Baud, P. (2020a). Towards more realistic values of elastic moduli for volcano modelling. Journal of Volcanology and Geothermal Research, 390, 106684.

Heap, M. J., Gravley, D. M., Kennedy, B. M., Gilg, H. A., Bertolett, E., \& Barker, S. L. (2020b). Quantifying the role of hydrothermal alteration in creating geothermal and epithermal mineral resources: The Ohakuri ignimbrite (Taupō Volcanic Zone, New Zealand). Journal of Volcanology and Geothermal Research, 390, 106703.

Heap, M. J., \& Violay, M. E. (2021). The mechanical behaviour and failure modes of volcanic rocks: a review. Bulletin of Volcanology, 83(5), 1-47.

Heap M.J., Baumann, T., Gilg, H.A., Kolzenburg, S., Ryan, A., Villeneuve, M., Russell, J.K., Kennedy, L., RosasCarbajal, M., \& Clynne M. (2021a) Hydrothermal alteration can result in pore pressurization and volcano instability. Geology, 49, https://doi.org/10.1130/G49063.1.

Heap, M. J., Wadsworth, F. B., Heng, Z., Xu, T., Griffiths, L., Velasco, A. A., ... \& Deegan, F. M. (2021b). The tensile strength of volcanic rocks: Experiments and models. Journal of Volcanology and Geothermal Research, 107348.

Hemley, J. J., Hostetler, P. B., Gude, A. J., \& Mountjoy, W. T. (1969). Some stability relations of alunite. Economic Geology, 64(6), 599-612.

Henley, R. W., \& Berger, B. R. (2011). Magmatic-vapor expansion and the formation of high-sulfidation gold deposits: Chemical controls on alteration and mineralization. Ore Geology Reviews, 39(1-2), 63-74.

Hincks, T. K., Komorowski, J. C., Sparks, S. R., \& Aspinall, W. P. (2014). Retrospective analysis of uncertain eruption precursors at La Soufrière volcano, Guadeloupe, 1975-77: volcanic hazard assessment using a Bayesian Belief Network approach. Journal of Applied Volcanology, 3(1), 3.

Hoek, E., \& Diederichs, M. S. (2006). Empirical estimation of rock mass modulus. International journal of rock mechanics and mining sciences, 43(2), 203-215.

Horwell, C. J., Williamson, B. J., Llewellin, E. W., Damby, D. E., \& Le Blond, J. S. (2013). The nature and formation of cristobalite at the Soufrière Hills volcano, Montserrat: implications for the petrology and stability of silicic lava domes. Bulletin of Volcanology, 75(3), 696.

Hurwitz, S., Kipp, K. L., Ingebritsen, S. E., \& Reid, M. E. (2003). Groundwater flow, heat transport, and water table position within volcanic edifices: Implications for volcanic processes in the Cascade Range. Journal of Geophysical Research: Solid Earth, 108(B12).

Inoue, A. (1995). Formation of clay minerals in hydrothermal environments. In: Origin and mineralogy of clays (pp. 268-329). Springer, Berlin, Heidelberg.

Jessop, D. E., Moune, S., Moretti, R., Gibert, D., Komorowski, J. C., Robert, V., ... \& Burtin, A. (2021). A multidecadal view of the heat and mass budget of a volcano in unrest: La Soufrière de Guadeloupe (French West Indies). Bulletin of Volcanology, 83(3), 1-19.

John, D. A., Sisson, T. W., Breit, G. N., Rye, R. O., \& Vallance, J. W. (2008). Characteristics, extent and origin of hydrothermal alteration at Mount Rainier Volcano, Cascades Arc, USA: Implications for debris-flow hazards and mineral deposits. Journal of Volcanology and Geothermal Research, 175(3), 289-314.

Karaman, K., \& Kesimal, A. (2015). Evaluation of the influence of porosity on the engineering properties of volcanic rocks from the Eastern Black Sea Region: NE Turkey. Arabian Journal of Geosciences, 8(1), $557-$ 564.

Kaus, B., Popov, A. A., Baumann, T., Pusok, A., Bauville, A., Fernandez, N., \& Collignon, M. (2016). Forward and inverse modelling of lithospheric deformation on geological timescales. In: Proceedings of NIC Symposium (Eds: Binder, K., Müller, M., Kremer, M., Schnurpfeil, A.), John von Neumann Institute for Computing (NIC), NIC Series, Vol. 48, ISBN 978-3-95806-109-5. 
Kennedy, B. M., Farquhar, A., Hilderman, R., Villeneuve, M. C., Heap, M. J., Mordensky, S., ... \& Reuschlé, T. (2020). Pressure controlled permeability in a conduit filled with fractured hydrothermal breccia reconstructed from ballistics from Whakaari (White Island), New Zealand. Geosciences, 10(4), 138.

Kereszturi, G., Schaefer, L. N., Miller, C., \& Mead, S. (2020). Hydrothermal Alteration on Composite Volcanoes: Mineralogy, Hyperspectral Imaging, and Aeromagnetic Study of Mt Ruapehu, New Zealand. Geochemistry, Geophysics, Geosystems, 21(9), e2020GC009270.

Kereszturi, G., Schaefer, L., Mead, S., Miller, C., Procter, J., \& Kennedy, B. (2021). Synthesis of hydrothermal alteration, rock mechanics and geophysical mapping to constrain failure and debris avalanche hazards at Mt. Ruapehu (New Zealand). New Zealand Journal of Geology and Geophysics, 1-22.

Kerle, N., \& De Vries, B. V. W. (2001). The 1998 debris avalanche at Casita volcano, Nicaragua-investigation of structural deformation as the cause of slope instability using remote sensing. Journal of Volcanology and Geothermal Research, 105(1-2), 49-63.

Komorowski, J.-C., Boudon, G., Semet, M., Beauducel, F., Anténor-Habazac, C., Bazin, S., \& Hammmouya, G. (2005). Guadeloupe. In: Volcanic Atlas of the Lesser Antilles (Eds: Lindsay, J., Robertson, R., Shepherd, J., \& Ali, S.), University of the Fnrech West Indies, Seismic Research Unit, pp. 65-102.

Komorowski J-C., Legendre, Y., Christopher, T., Bernstein, L., R. Stewart, Joseph, E., Fournier, N., Chardot, L., Finizola, A., Wadge, G., Syers, R., Williams, C, Bass, V. (2010), Insights into processes and deposits of hazardous vulcanian explosions at Soufrière Hills Volcano during 2008 and 2009 (Montserrat, West Indies), Geophysical Research Letters, 37, L00E19, doi :10.1029/2010GL042558.

Komorowski, J.-C., Hincks, T., Sparks, R., Aspinall, W., \& CASAVA ANR Project Consortium. (2015). Improving crisis decision-making at times of uncertain volcanic unrest (Guadeloupe, 1976). In: Global Volcanic Hazards and Risk (Eds: Loughlin, S.C., Sparks, R.S.J., Brown, S.K., Jenkins, S.F., \& Vye-Brown, C), Cambridge University Press, pp 255-261.

Le Friant, A., Boudon, G., Komorowski, J. C., Heinrich, P., \& Semet, M. P. (2006). Potential flank-collapse of Soufriere Volcano, Guadeloupe, lesser Antilles? Numerical simulation and hazards. Natural Hazards, 39(3), 381.

Lesparre, N., Gibert, D., Marteau, J., Komorowski, J. C., Nicollin, F., \& Coutant, O. (2012). Density muon radiography of La Soufriere of Guadeloupe volcano: comparison with geological, electrical resistivity and gravity data. Geophysical Journal International, 190(2), 1008-1019.

López, D. L., \& Williams, S. N. (1993). Catastrophic volcanic collapse: relation to hydrothermal processes. Science, 260(5115), 1794-1796.

Marini, L., Zuccolini, M. V., \& Saldi, G. (2003). The bimodal pH distribution of volcanic lake waters. Journal of Volcanology and Geothermal Research, 121(1-2), 83-98.

Martel, C., Pichavant, M., Di Carlo, I., Champallier, R., Wille, G., Castro, J. M., ... \& Kushnir, A. R. (2021). Experimental Constraints on the Crystallization of Silica Phases in Silicic Magmas. Journal of Petrology, 62(1), egab004.

Mayer, K., Scheu, B., Gilg, H. A., Heap, M. J., Kennedy, B. M., Lavallée, Y., ... \& Dingwell, D. B. (2015). Experimental constraints on phreatic eruption processes at Whakaari (White Island volcano). Journal of Volcanology and Geothermal Research, 302, 150-162.

Mayer, K., Scheu, B., Montanaro, C., Yilmaz, T. I., Isaia, R., Aßbichler, D., \& Dingwell, D. B. (2016). Hydrothermal alteration of surficial rocks at Solfatara (Campi Flegrei): Petrophysical properties and implications for phreatic eruption processes. Journal of Volcanology and Geothermal Research, 320, 128143.

Mayer, K., Scheu, B., Yilmaz, T. I., Montanaro, C., Gilg, H. A., Rott, S., ... \& Dingwell, D. B. (2017). Phreatic activity and hydrothermal alteration in the Valley of Desolation, Dominica, Lesser Antilles. Bulletin of Volcanology, 79(12), 82.

McCollom, T. M., Hynek, B. M., Rogers K., Moskowitz, B., \& Berquó, T. S. (2013). Chemical and mineralogical trends during acid-sulfate alteration of pyroclastic basalt at Cerro Negro volcano and implications for early Mars. Journal of Geophysical Research, Planets, 118, 1719-1751.

Metcalfe, A., Moune, S., Komorowski, J. C., Kilgour, G., Jessop, D. E., Moretti, R., \& Legendre, Y. (2021). Magmatic Processes at La Soufrière de Guadeloupe: Insights From Crystal Studies and Diffusion Timescales for Eruption Onset. Frontiers in Earth Science, 9, 78.

Meyer, C., \& Hemley, J. J. (1967). Wall rock alteration in Barnes, HL (ed.) Geochemistry of hydrothermal ore deposits. Holt, Reinhart and Winston. Inc., New York.

Mick, E., Stix, J., de Moor, J. M., \& Avard, G. (2021). Hydrothermal alteration and sealing at Turrialba volcano, Costa Rica, as a mechanism for phreatic eruption triggering. Journal of Volcanology and Geothermal Research, 107297.

Montanaro, C., Scheu, B., Mayer, K., Orsi, G., Moretti, R., Isaia, R., \& Dingwell, D. B. (2016). Experimental investigations on the explosivity of steam-driven eruptions: A case study of Solfatara volcano (Campi Flegrei). Journal of Geophysical Research: Solid Earth, 121(11), 7996-8014. 
Mordensky, S. P., Villeneuve, M. C., Kennedy, B. M., Heap, M. J., Gravley, D. M., Farquharson, J. I., \& Reuschlé, T. (2018). Physical and mechanical property relationships of a shallow intrusion and volcanic host rock, Pinnacle Ridge, Mt. Ruapehu, New Zealand. Journal of Volcanology and Geothermal Research, 359, 120.

Mordensky S., Heap M., Kennedy B., Gilg A., Villeneuve M., Farquharson J. and Gravley D. (2019) Influence of alteration on the mechanical behaviour and failure mode of andesite: implications for shallow seismicity and volcano monitoring. Bulletin of Volcanology, 81:44.

Moretti, R., Komorowski, J. C., Ucciani, G., Moune, S., Jessop, D., de Chabalier, J. B., ... \& Deroussi, S. (2020). The 2018 unrest phase at La Soufrière of Guadeloupe (French West Indies) andesitic volcano: Scrutiny of a failed but prodromal phreatic eruption. Journal of Volcanology and Geothermal Research, 393, 106769.

Mueller, D., Bredemeyer, S., Zorn, E., De Paolo, E., \& Walter, T. R. (2021). Surveying fumarole sites and hydrothermal alteration by unoccupied aircraft systems (UAS) at the La Fossa cone, Vulcano Island (Italy). Journal of Volcanology and Geothermal Research, 413, 107208.

Nicolas, A., Lévy, L., Sissmann, O., Li, Z., Fortin, J., Gibert, B., \& Sigmundsson, F. (2020). Influence of hydrothermal alteration on the elastic behaviour and failure of heat-treated andesite from Guadeloupe. Geophysical Journal International, 223(3), 2038-2053.

Nicollin, F., Gibert, D., Beauducel, F., Boudon, G., \& Komorowski, J. C. (2006). Electrical tomography of La Soufrière of Guadeloupe Volcano: Field experiments, 1D inversion and qualitative interpretation. Earth and Planetary Science Letters, 244(3-4), 709-724.

Opfergelt, S., Delmelle, P., Boivin, P., \& Delvaux, B. (2006). The 1998 debris avalanche at Casita volcano, Nicaragua: Investigation of the role of hydrothermal smectite in promoting slope instability. Geophysical Research Letters, 33(15).

Peruzzetto, M., Komorowski, J.-C., Le Friant, A., Rosas-Carbajal, M., Mangeney, A., \& Legendre, Y. (2019). Modeling of partial dome collapse of La Soufrière of Guadeloupe volcano: implications for hazard assessment and monitoring. Scientific Reports, 9(1), 1-15.

Pusok, A. E., \& Kaus, B. J. (2015). Development of topography in 3-D continental-collision models. Geochemistry, Geophysics, Geosystems, 16(5), 1378-1400.

Reid, M. E., Sisson, T. W., \& Brien, D. L. (2001). Volcano collapse promoted by hydrothermal alteration and edifice shape, Mount Rainier, Washington. Geology, 29(9), 779-782.

Reid, M. E. (2004). Massive collapse of volcano edifices triggered by hydrothermal pressurization. Geology, 32(5), 373-376.

Reuber, G. S., Kaus, B. J., Popov, A. A., \& Baumann, T. S. (2018). Unraveling the physics of the Yellowstone magmatic system using geodynamic simulations. Frontiers in Earth Science, 6, 117.

Rosas-Carbajal, M., Komorowski, J. C., Nicollin, F., \& Gibert, D. (2016). Volcano electrical tomography unveils edifice collapse hazard linked to hydrothermal system structure and dynamics. Scientific reports, 6, 29899.

Rosas-Carbajal, M., Jourde, K., Marteau, J., Deroussi, S., Komorowski, J. C., \& Gibert, D. (2017). Threedimensional density structure of La Soufrière de Guadeloupe lava dome from simultaneous muon radiographies and gravity data. Geophysical Research Letters, 44(13), 6743-6751.

Roverato, M., Di Traglia, F., Procter, J., Paguican, E., \& Dufresne, A. (2021). Factors contributing to volcano lateral collapse. In Volcanic Debris Avalanches (pp. 91-119). Springer, Cham.

Rye, R. O., Bethke, P. M., \& Wasserman, M. D. (1992). The stable isotope geochemistry of acid sulfate alteration. Economic Geology, 87(2), 225-262.

Salaün, A., Villemant, B., Gérard, M., Komorowski, J. C., \& Michel, A. (2011). Hydrothermal alteration in andesitic volcanoes: trace element redistribution in active and ancient hydrothermal systems of Guadeloupe (Lesser Antilles). Journal of Geochemical Exploration, 111(3), 59-83.

Samaniego, P., Valderrama, P., Mariño, J., van Wyk de Vries, B., Roche, O., Manrique, N., ... \& Malnati, J. (2015). The historical $(218 \pm 14 \mathrm{aBP})$ explosive eruption of Tutupaca volcano (Southern Peru). Bulletin of Volcanology, 77(6), 1-18.

Schaefer, L. N., Kendrick, J. E., Oommen, T., Lavallée, Y., \& Chigna, G. (2015). Geomechanical rock properties of a basaltic volcano. Frontiers in Earth Science, 3, 29.

Schipper, C. I., Rickard, W. D., Reddy, S. M., Saxey, D. W., Castro, J. M., Fougerouse, D., ... \& Lilly, K. (2020). Volcanic SiO2-cristobalite: A natural product of chemical vapor deposition. American Mineralogist: Journal of Earth and Planetary Materials, 105(4), 510-524.

Siebert, L. (1984) Large volcanic debris avalanches: characteristics of source areas, deposits, and associated eruptions. Journal of Volcanology and Geothermal Research 22, 163-197.

Siebert, L., Glicken, H. \& Ui, T. (1987). Volcanic hazards from Bezymianny- and Bandai-type eruptions. Bulletin of Volcanology 49, 435-459.

Siebert, L., Simkin, T. \& Kimberly, P. Volcanoes of the World (Univ of California Press, 2010). 
Siratovich, P. A., Heap, M. J., Villenueve, M. C., Cole, J. W., \& Reuschlé, T. (2014). Physical property relationships of the Rotokawa Andesite, a significant geothermal reservoir rock in the Taupo Volcanic Zone, New Zealand. Geothermal Energy, 2(1), 1-31.

Sparks, R.S.J., Barclay, J., Calder, E.S., Herd, R.A., Komorowski, J-C., Norton, G.E., Ritchie, L., Voight, B., Woods, A.W. (2002) Generation of a debris avalanche and violent pyroclastic density current: the Boxing Day eruption of 26 December 1997 at the Soufrière Hills Volcano, Montserrat. In: T.H. Druitt, B.P. Kokelaar (Eds), The eruption of Soufrière Hills Volcano, Montserrat, from 1995 to 1999, Geological Society, London, Memoirs, 21, 409-43

Stoffregen, R. E., \& Cygan, G. L. (1990). An experimental study of Na-K exchange between alunite and aqueous sulfate solutions. American Mineralogist, 75(1-2), 209-220.

Stoffregen, R. E., Alpers, C. N., \& Jambor, J. L. (2000). Alunite-jarosite crystallography, thermodynamics, and geochronology. Reviews in Mineralogy and Geochemistry, 40(1), 453-479.

Tamburello, G., Moune, S., Allard, P., Venugopal, S., Robert, V., Rosas-Carbajal, M., ... \& Moretti, R. (2019). Spatio-temporal relationships between fumarolic activity, hydrothermal fluid circulation and geophysical signals at an arc volcano in degassing unrest: La Soufrière of Guadeloupe (French West Indies). Geosciences, 9(11), 480.

Tanaka, H. K., Taira, H., Uchida, T., Tanaka, M., Takeo, M., Ohminato, T., ... \& Tsuiji, H. (2010). Threedimensional computational axial tomography scan of a volcano with cosmic ray muon radiography. Journal of Geophysical Research: Solid Earth, 115(B12).

Taran, Y., \& Kalacheva, E. (2020). Acid sulfate-chloride volcanic waters; Formation and potential for monitoring of volcanic activity. Journal of Volcanology and Geothermal Research, 107036.

van Wyk de Vries, B., \& Francis, P. W. (1997). Catastrophic collapse at stratovolcanoes induced by gradual volcano spreading. Nature, 387(6631), 387-390.

van Wyk de Vries, B., Kerle, N., \& Petley, D. (2000). Sector collapse forming at Casita volcano, Nicaragua. Geology, 28(2), 167-170.

Vásárhelyi, B. (2009). A possible method for estimating the Poisson's rate values of the rock masses. Acta Geodaetica et Geophysica Hungarica, 44(3), 313-322.

Villemant, B, Hammouya, G, Michel, A., Semet, M., Komorowski J-C, Boudon, G., Cheminée, J-L. (2005) The memory of volcanic waters: shallow magma degassing revealed by halogen monitoring in thermal springs of La Soufrière volcano (Guadeloupe, Lesser Antilles), Earth Planet. Sci. Letters, 237: 710-728.

Villemant, B., Komorowski, J. C., Dessert, C., Michel, A., Crispi, O., Hammouya, G., ... \& De Chabalier, J. B. (2014). Evidence for a new shallow magma intrusion at La Soufrière of Guadeloupe (Lesser Antilles): insights from long-term geochemical monitoring of halogen-rich hydrothermal fluids. Journal of Volcanology and Geothermal Research, 285, 247-277.

Voight B., Glicken, H., Janda, R.J., Douglass, P.M. (1981) Catastrophic rockslide avalanche of May 18. In: Lipman, P. W. \& Mullineaux, D. R. (Eds) The 1980 Eruptions of Mount St Helens, Washington, US Geological Survey, Professional Papers, 1250, 347-378.

Voight, B., Komorowski J-C., Norton, G.E., Belousov, A.B., Belousova, M., Boudon, G., Francis, P.W., Franz, W., Heinrich, P., Sparks, R.S.J. \& Young, S.R. (2002) The 1997 Boxing Day Sector Collapse and Debris Avalanche, Soufriere Hills Volcano, Montserrat, W.I. In: T.H. Druitt, B.P. Kokelaar (Eds), The eruption of Soufrière Hills Volcano, Montserrat, from 1995 to 1999, Geological Society, London Memoirs, 21, 363407

Watters, R. J., \& Delahaut, W. D. (1995). Effect of argillic alteration on rock mass stability. Clay and Shale Slope Instability, 10, 139.

Watters, R. J., Zimbelman, D. R., Bowman, S. D., \& Crowley, J. K. (2000). Rock mass strength assessment and significance to edifice stability, Mount Rainier and Mount Hood, Cascade Range volcanoes. Pure and Applied Geophysics, 157(6-8), 957-976.

Wyering, L. D., Villeneuve, M. C., Wallis, I. C., Siratovich, P. A., Kennedy, B. M., Gravley, D. M., \& Cant, J. L. (2014). Mechanical and physical properties of hydrothermally altered rocks, Taupo Volcanic Zone, New Zealand. Journal of Volcanology and Geothermal Research, 288, 76-93.

Yilmaz, T. I., Wadsworth, F. B., Gilg, H. A., Hess, K. U., Kendrick, J. E., Wallace, P. A., ... \& Dingwell, D. B. (2021). Rapid alteration of fractured volcanic conduits beneath Mt Unzen. Bulletin of Volcanology, 83(5), $1-14$.

Zhu, W., Baud, P., Vinciguerra, S., \& Wong, T. F. (2016). Micromechanics of brittle faulting and cataclastic flow in Mount Etna basalt. Journal of Geophysical Research: Solid Earth, 121(6), 4268-4289.

Zimbelman, D. R., Rye, R. O., \& Breit, G. N. (2005). Origin of secondary sulfate minerals on active andesitic stratovolcanoes. Chemical Geology, 215(1-4), 37-60. 